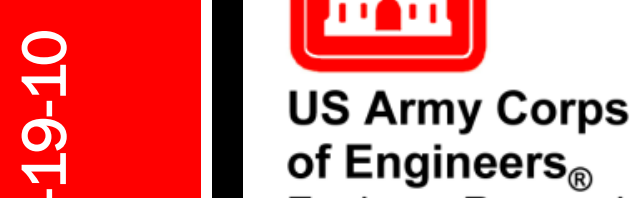

\title{
HERDC
}

Engineer Research and

Development Center

\section{Raven Rock Mountain Complex Site R, PA Archaeological Site Revisit}

Carey. L. Baxter, Adam D. Smith, and Ellen R. Hartman

August 2019

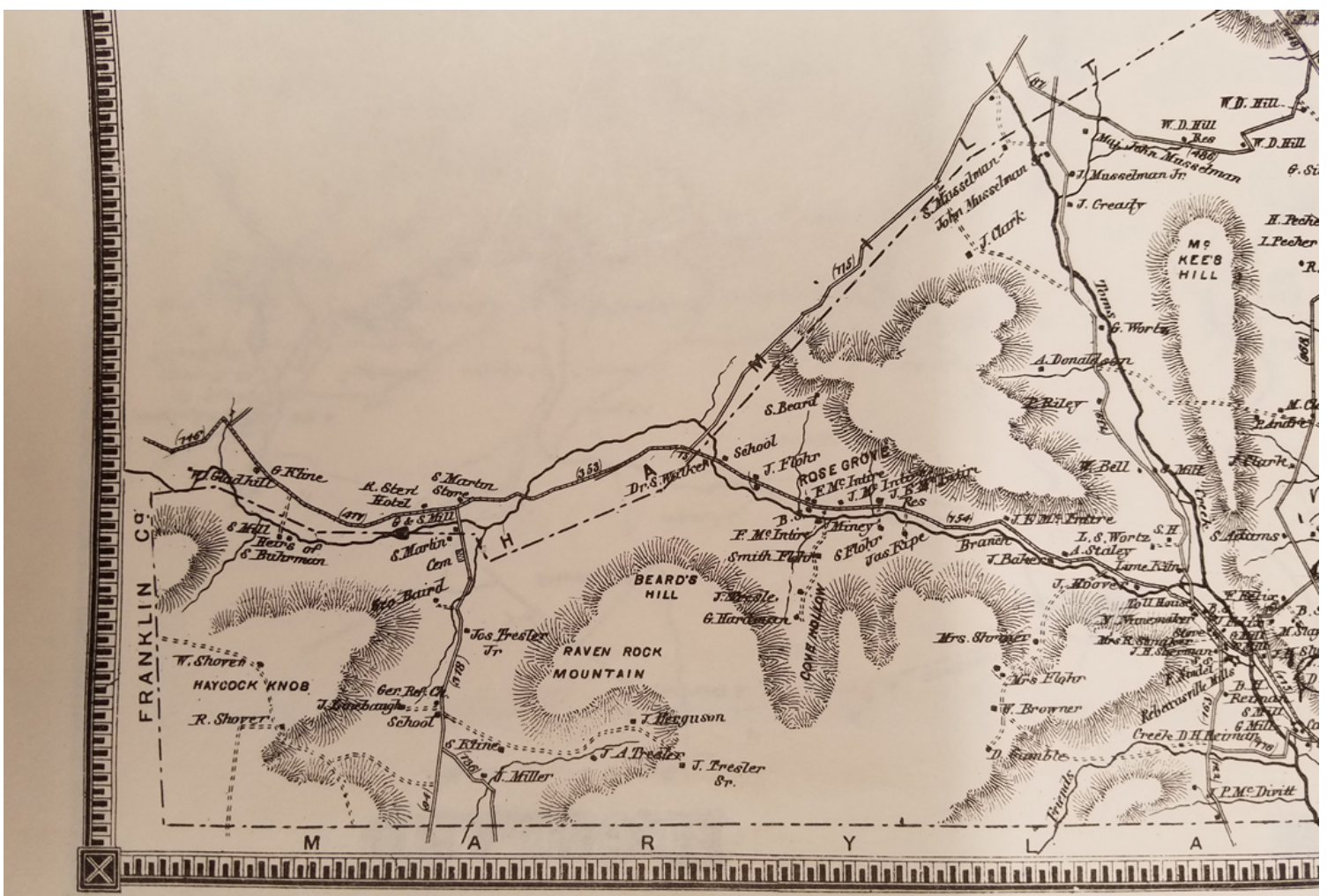

Approved for public release; distribution is unlimited. 
The U.S. Army Engineer Research and Development Center (ERDC) solves the nation's toughest engineering and environmental challenges. ERDC develops innovative solutions in civil and military engineering, geospatial sciences, water resources, and environmental sciences for the Army, the Department of Defense, civilian agencies, and our nation's public good. Find out more at www.erdc.usace.army.mil.

To search for other technical reports published by ERDC, visit the ERDC online library at http://acwc.sdp.sirsi.net/client/default.

Cover Photo: Portion of Atlas of Adams County Pennsylvania, 1872 (Adams County Historical Society). 


\section{Raven Rock Mountain Complex Site R, PA Archaeological Site Revisit}

Carey. L. Baxter, Adam D. Smith, and Ellen R. Hartman

U.S. Army Engineer Research and Development Center (ERDC)

Construction Engineering Research Laboratory (CERL)

2902 Newmark Dr.

Champaign, IL 61824

Final Technical Report (TR)

Approved for public release; distribution is unlimited.

Prepared for Environmental, Safety, and Health Division

Raven Rock Mountain Complex

Fairfield, PA 17320

Under Project 469449, “Work for RRMC 


\section{Abstract}

The U.S. Congress codified the National Historic Preservation Act of 1966 (NHPA) in part by establishing the National Register of Historic Places (NRHP), which requires federal agencies to address their cultural resources. NHPA Section 110 requires federal agencies to inventory and evaluate their cultural resources, and Section 106 requires them to determine the effect of federal undertakings on those potentially eligible for the NRHP.

In 2017, ERDC-CERL was tasked with conducting a Phase I Archaeological survey of Raven Rock Mountain Complex (RRMC) Site R in Pennsylvania, which was built in 1951 and is now a division of the Washington Headquarters Service. In 2001, U.S. Army Corps of Engineers Baltimore District conducted an archaeological Phase I survey of the Site R facility. A 2017 historical resources survey of the facility recommended additional archaeological resources research to supplement the 2001 survey. This report provides supplemental historic context and field documentation of archaeological sites and features described in the 2001 report. In consultation with the Pennsylvania State Historic Preservation Officer, this work fulfills Section 110 processes for the land at Site R.

DISCLAIMER: The contents of this report are not to be used for advertising, publication, or promotional purposes. Citation of trade names does not constitute an official endorsement or approval of the use of such commercial products. All product names and trademarks cited are the property of their respective owners. The findings of this report are not to be construed as an official Department of the Army position unless so designated by other authorized documents.

DESTROY THIS REPORT WHEN NO LONGER NEEDED. DO NOT RETURN IT TO THE ORIGINATOR. 


\section{Contents}

Abstract
Figures and Tables.

2 History and Setting of Raven Rock Mountain Site R ........................................................ 5

2.1 Environmental Setting ..................................................................................... 5

2.2 Prehistoric Context................................................................................................... 6

2.3 Historic Context............................................................................................... 7

3 Site Revisits and Supplemental Research....................................................................... 9

3.1 Historic Site Location A................................................................................. 11

3.2 Historic Site B................................................................................................ 17

3.3 Rock Walls.................................................................................................... 21

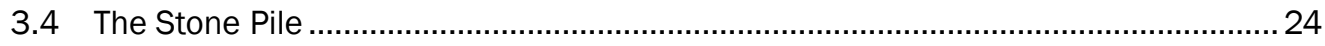

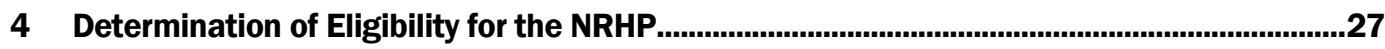

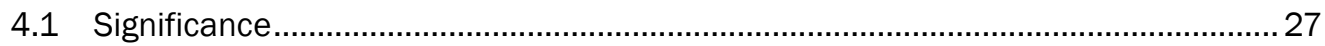

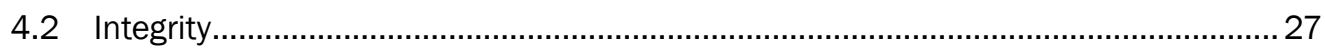

4.3 Findings at Raven Rock Mountain Complex Site R ................................................28

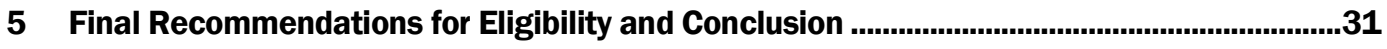

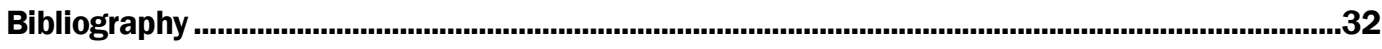

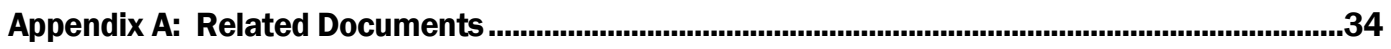

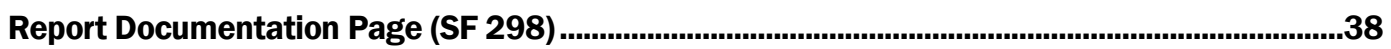




\section{Figures and Tables}

\section{Figures}

1 Location of Raven Rock Mountain Complex Site R, in south-central

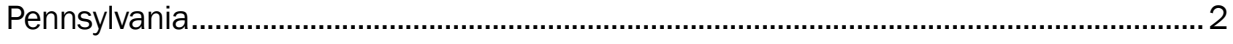

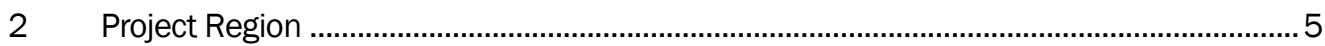

3 RRMC showing location of sites and property boundaries .............................................10

$4 \quad$ RRMC with locations of historic buildings and roads.....................................................10

$5 \quad$ Map of the southern portion of RRMC, 1872 .................................................................11

$6 \quad$ Portion of Quadrangle Map and Historic Site A. 191 ........................................................11

$7 \quad$ Register of Acquisition map, dated 2/12/1953 ..............................................................13

8 Property map B-18 Liberty and Hamiltonban Township on file at Adams County Courthouse. This map is undated but probably dates to 1952 ...........................13

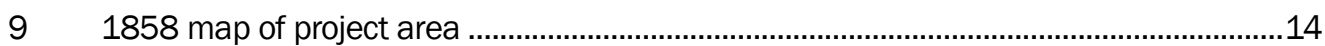

10 Historic Site A depicted on 1938 aerial map ...................................................................15

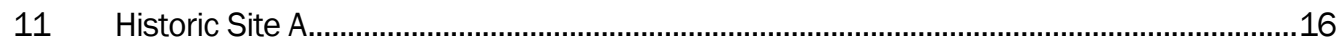

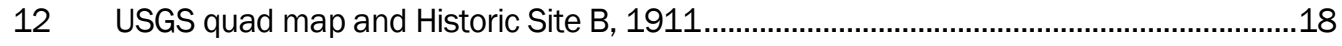

13 Historic Site B depicted on 1938 aerial map.....................................................................18

141872 map showing the various Martins in the area of Raven Rock

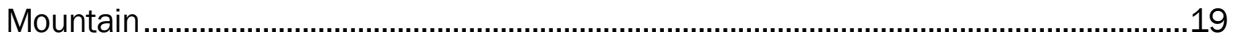

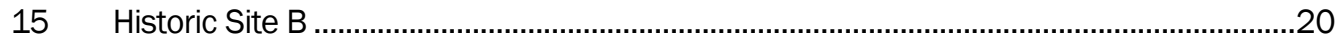

16 Rock Walls and field boundaries at Raven Rock Mountain ..............................................22

17 Rock walls in relationship to 1952 property deed map ...................................................22

18 Rock wall near road in SW Adams County, Pennsylvania.................................................23

19 Rock wall among trees in southwest Adams County, Pennsylvania ...............................23

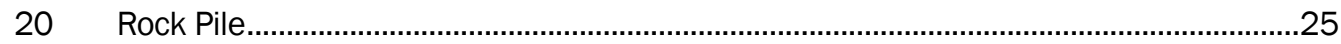

A-1 2002 letter from the Pennsylvania Historical and Museum Commission (PHMC) to Fort Detrick in regards to the 2001 Baltimore District survey of Site R.

A-2 2009 letter from Gettysburg National Military Park in regards to the stone structure near the East Gate

A-3 2010 letter from PHMC in regards to the stone structure near the East Gate .

\section{Tables}

1 Chain of Title, Tract A113 (data from Adams County Courthouse, Office of the Recorder of Deeds)

2 Chain of Title, Tract A114 (data from Adams County Courthouse, Office of the Recorder of Deeds). 


\section{Preface}

This study was conducted for the Cultural Resources Program, Environmental, Safety, and Health Division, of Raven Rock Mountain Complex, under Project 469449, "Work for RRMC." The technical monitor was Donna Swauger, Environmental Protection Specialist, Raven Rock Mountain Complex.

The work was performed by the Land and Heritage Conservation Branch (CNC) of the Installations Divisions (CN), U.S. Army Engineer Research and Development Center - Construction Engineering Research Laboratory (ERDC-CERL). At the time of publication, Dr. Michael L. Hargrave was Chief, CEERD-CNC, and Ms. Michelle J. Hanson was Chief, CEERD-CN. The Deputy Director of ERDC-CERL was Dr. Kirankumar Topudurti, and the Director was Dr. Lance D. Hansen.

COL Ivan P. Beckman was Commander of ERDC, and Dr. David W. Pittman was the Director. 


\section{Unit Conversion Factors}

\begin{tabular}{|l|l|l|}
\hline Multiply & By & To Obtain \\
\hline acres & $4,046.873$ & square meters \\
\hline feet & 0.3048 & meters \\
\hline inches & 0.0254 & meters \\
\hline miles (U.S. statute) & $1,609.347$ & meters \\
\hline square feet & 0.09290304 & square meters \\
\hline yards & 0.9144 & meters \\
\hline
\end{tabular}




\section{Abbreviations}

$\begin{array}{ll}\text { Term } & \text { Definition } \\ \text { AJCC } & \text { Alternate Joint Communications Center } \\ \text { ANSI } & \text { American National Standards Institute } \\ \text { BCP } & \text { BRAC Cleanup Plan } \\ \text { BRAC } & \text { Base Realignment and Closure } \\ \text { CERL } & \text { Construction Engineering Research Laboratory } \\ \text { DoD } & \text { U.S. Department of Defense } \\ \text { DoDI } & \text { Department of Defense Instruction } \\ \text { ERDC } & \text { U.S. Army Engineer Research and Development Center } \\ \text { ERDC-CERL } & \text { Engineer Research and Development Center, Construction Engineering } \\ \text { GIS } & \text { Research Laboratory } \\ \text { GPS } & \text { Geographic Information System } \\ \text { HAER } & \text { Global Positioning System } \\ \text { ICRMP } & \text { Historic American Engineering Record } \\ \text { IPUMS } & \text { Integrated Cultural Resources Management Plan } \\ \text { LiDAR } & \text { Integrated Public Use Microdata Series } \\ \text { LOC } & \text { Light Detection and Ranging } \\ \text { NHPA } & \text { Library of Congress } \\ \text { NPS } & \text { National Historic Preservation Act of 1966 } \\ \text { NRCS } & \text { National Park Service } \\ \text { NRHP } & \text { Natural Resources Conservation Service } \\ \text { NSN } & \text { National Register of Historic Places } \\ \text { OMB } & \text { National Supply Number } \\ \text { PHMC } & \text { Office of Management and Budget } \\ \text { RRMC } & \text { Pennsylvania Historical and Museum Commission } \\ \text { SF } & \text { Raven Rock Mountain Complex } \\ \text { USDA } & \text { Standard Form } \\ \text { USGS } & \text { U.S. Department of Agriculture } \\ & \text { U.S. Department of the Interior Geologic Survey } \\ & \end{array}$


THIS PAGE INTENTIONALLY LEFT BLANK 


\section{Methodology}

\subsection{Background}

The U.S. Congress codified the National Historic Preservation Act of 1966 (NHPA), the nation's most effective cultural resources legislation to date, to provide guidelines and requirements for identifying tangible elements of our nation's past. This legislative requirement was met through creation of the National Register of Historic Places (NRHP). Contained within this piece of legislation (NHPA Sections 110 and 106) are requirements for federal agencies to address their cultural resources, defined as any prehistoric or historic district, site, building, structure, or object. Section 110 requires federal agencies to inventory and evaluate their cultural resources. Section 106 requires the determination of effect of federal undertakings on properties deemed eligible or potentially eligible for the NRHP.

Raven Rock Mountain Complex (RRMC) is a Department of Defense (DoD) facility located at Raven Rock Mountain near Blue Ridge Summit in Adams County, Pennsylvania. In 1951, the U.S. Army began construction of the facility, which opened in 1953. Raven Rock Mountain Complex Site R is located in south-central Pennsylvania (Figure 1).

There are DoD specific mandates regarding historic properties that supplement and support Section 106 and Section 110. Department of Defense Instruction (DoDI) 4715.16 requires places under DoD control to develop Integrated Cultural Resource Management Plans (ICRMPs). As part of the ICRMP and pursuant to the NHPA, DoD facilities are required to identify and manage historic properties on their lands.

In 2001, the U.S. Army Corps of Engineers Baltimore District performed an archaeological Phase I survey of Raven Rock Mountain Complex Site R (RRMC Site R), which was documented in a report titled Phase 1 Cultural Resource Investigation, Alternative Joint Communications Center Site $R$ Raven Rock Mountain (Baltimore District 2001). The report was submitted to the U.S. Army Garrison Fort Detrick, Directorate of Installation Services, Environmental Management Office. The report is kept on file at the RRMC environmental office. 
Figure 1. Location of Raven Rock Mountain Complex Site R, in south-central Pennsylvania.

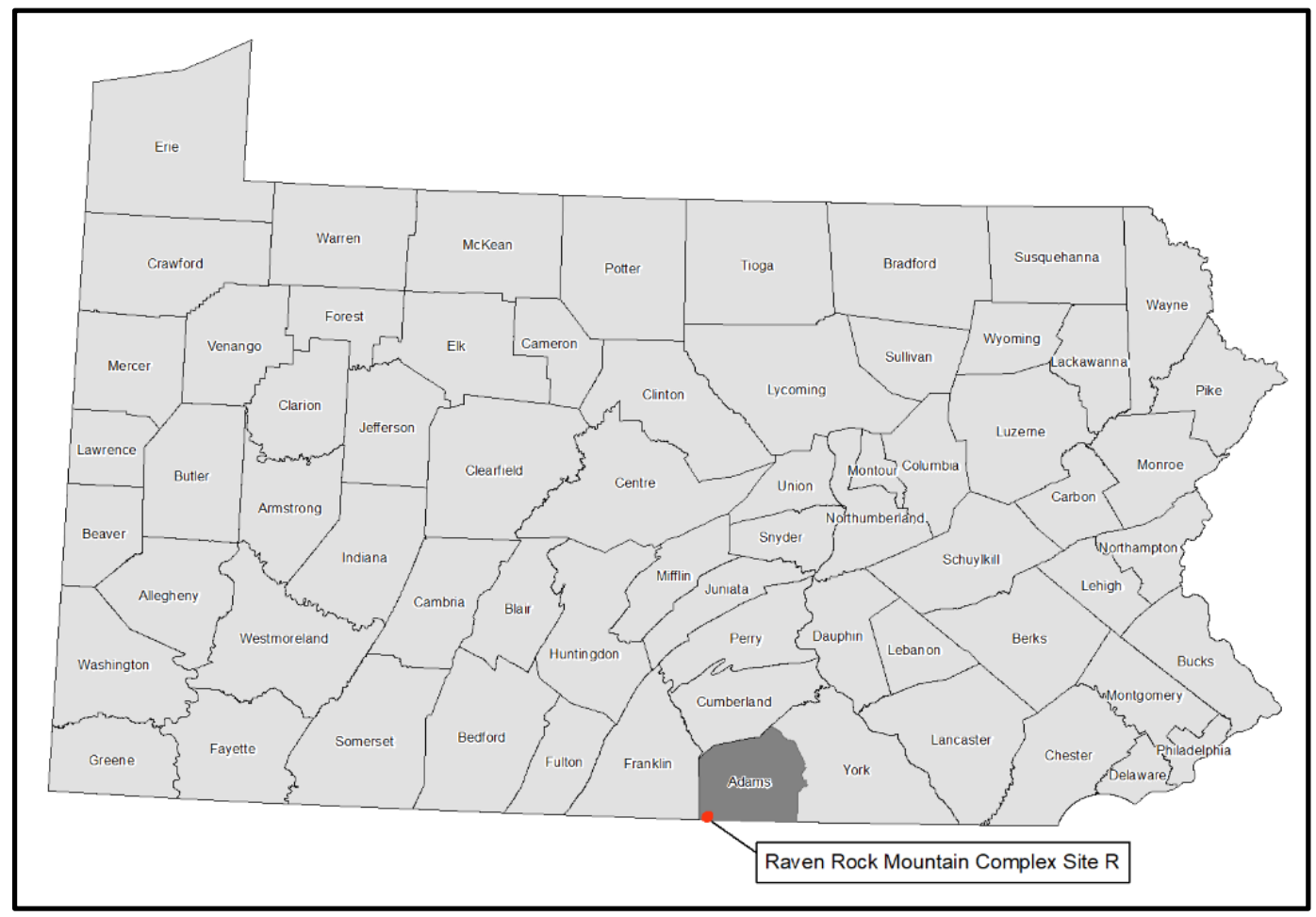

Source: ERDC-CERL (2018).

In 2017, RRMC tasked ERDC-CERL to conduct a historical resources survey of the compound and to assist in the generation of an ICRMP. During examination of the historic documentation held at RRMC, it was determined that additional research into the archaeological resources located on the mountain surface would be advisable. This work, which supplements the Phase I survey report (Baltimore 2001), was undertaken to provide needed documentation of the additional historical research conducted as part of the ICRMP generation. As such, this report addresses only the archaeological resources that existed on Raven Rock Mountain before DoD began to use the site. Specifically, this report includes additional historic context for the historic farmstead sites at RRMC and documentation of the rock walls that occur throughout the installation.

\subsection{Objective}

The objective of this work was to supplement the archaeological Phase I survey of Raven Rock Mountain Complex Site R (Baltimore 2001) and to provide needed documentation of the additional historical research conducted as part of the ICRMP generation. 


\subsection{Researchers}

This project was conducted by the U.S. Army Corps of Engineers, Engineering Research Development Center, Construction and Engineering Research Laboratory (ERDC-CERL) in Champaign, Illinois. The research team included Carey L. Baxter, Bachelor of Arts as lead archaeologist, with 18 years of experience in prehistoric and historic archaeology; Adam D. Smith, Master of Architecture, as project manager, with 20 years of experience in military architectural history; and Ellen R. Hartman, Master of Landscape Architecture, as research and field assistant, with 10 years of experience.

\subsection{Approach}

\subsubsection{Site visits}

ERDC-CERL personnel made three trips to Site $\mathrm{R}$ and Site $\mathrm{C}$ at RRMC to inventory historic materials, to conduct archival research at local and regional archives, and to map features at Site R in December 2017, February 2018, and March 2018. During those weeks, team members conducted site revisits and reevaluations of all archaeological resources at Site R.

\subsubsection{Archival repositories}

ERDC-CERL researchers conducted a review of books, archival repositories, and online resources related to the Raven Rock area before the establishment of RRMC in 1951. The following places were contacted and/or searched:

- NRHP listings and nomination forms (online at https://www.nps.gov/Nr/publications/index.htm);

- Historic drawings, maps, photographs, and information provided by the Environmental, Safety, and Health Division and the Geographic Information System (GIS) office at RRMC;

- Pennsylvania State Historic Preservation Office (online at https://www.phmc.pa.gov/Preservation/Pages/default.aspx);

- United States Library of Congress Maps Division (online at https://www.loc.gov/maps/collections/?st=gallery);

- The Integrated Public Use Microdata Series (IPUMS) U.S Census Data collections (online at https://usa/ipums.org/usa/index.shtml);

- Adams County Historical Society, Gettysburg, Pennsylvania;

- Adams County Court House, Gettysburg, Pennsylvania;

- Adams County Public Library, Gettysburg, Pennsylvania;

- Gettysburg National Military Park, Gettysburg, Pennsylvania; 
- Blue Ridge Summit Free Library, Blue Ridge Summit, Pennsylvania;

- Alexander Hamilton Memorial Free Library, Waynesboro, Pennsylvania;

- Smithsburg Library, Smithsburg, Maryland;

- Western Maryland Room, Washington County Free Library, Hagerstown, Maryland.

\subsubsection{Analysis and evaluation}

After initial research was completed, the team analyzed the gathered information. Archival information and field information were integrated throughout the course of the project. The information available was contained in text documents, photographs, and historic maps. Using archival sources, the research team extracted relevant historical information. The material was then combined to tell the story in both text and images.

A cultural resource can retain or lose its historic integrity, meaning that it either does or does not convey its historic significance. From this evaluation process, a recommendation of eligibility for listing on the NRHP was made. The evaluation adhered to the following guidelines:

- National Register Bulletin \#15, How to Apply the National Register Criteria for Evaluation (NPS 1997a);

- National Register Bulletin \#16A, How to Complete the National Register Registration Form (NPS 1997b);

- National Register Bulletin, How to Prepare National Historic Landmark Nominations (NPS 1999);

- The Secretary of the Interior's Standards for the Treatment of Historic Properties with Guidelines for the Treatment of Cultural Landscapes (Grimmer 2017). 


\section{History and Setting of Raven Rock Mountain Site R}

This chapter briefly describes Raven Rock Mountain. For a more complete description, refer to the U.S. Army Corps of Engineers, Baltimore District (2001) report.

\subsection{Environmental Setting}

Figure 2. Project Region.

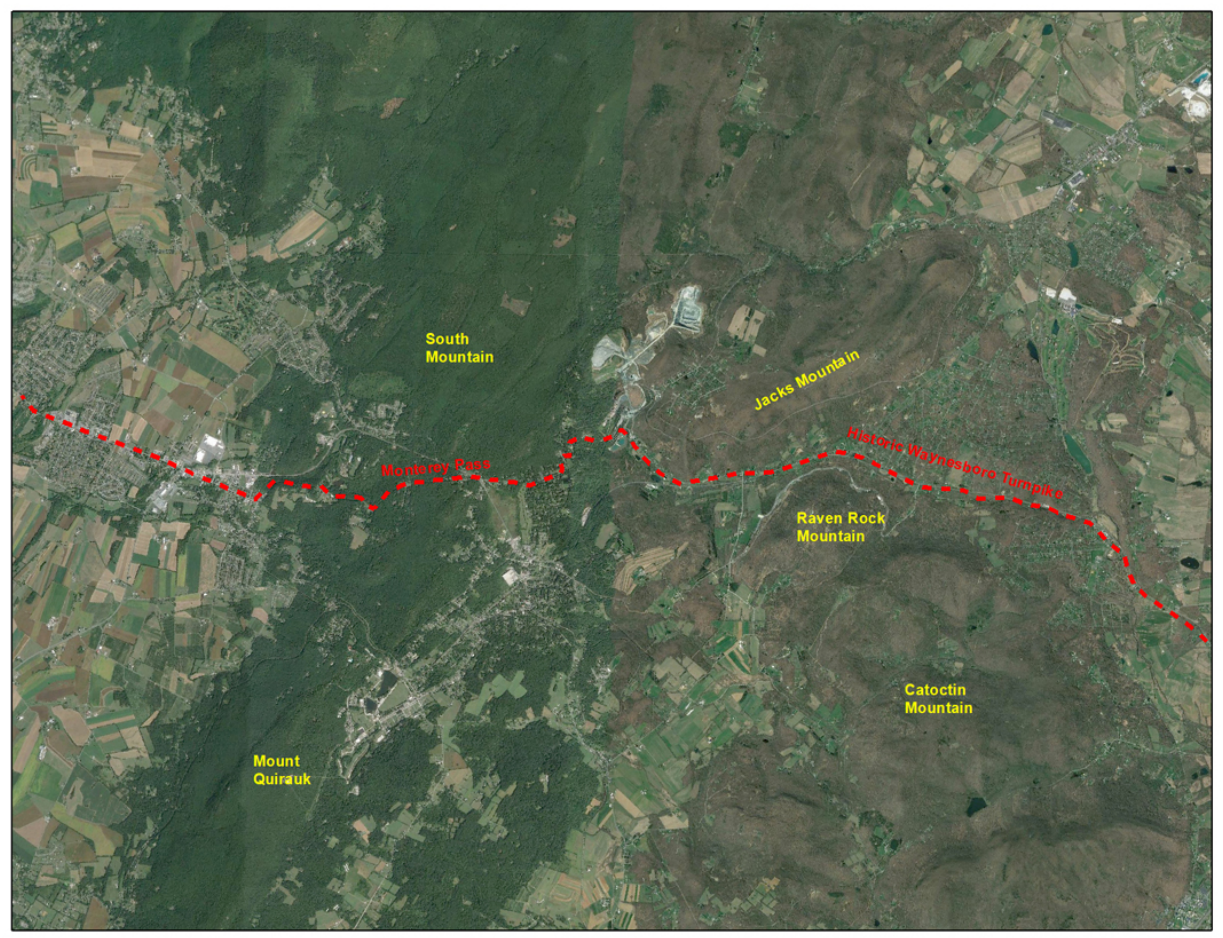

Source: ERDC-CERL (2019).

Adams County lies mostly in the Piedmont province of Pennsylvania. Most of the county is dominantly undulating to rolling, and is dissected by many drainage ways and streams (Figure 2). Some of the county is nearly level. Hills are scattered throughout much of the Piedmont area. South Mountain, in the western and northern parts of the county, is in the Blue Ridge province, which has hills, ridges, and narrow valleys. Of the county's two main watersheds, the northern half drains into the Susquehanna River largely by the way of the Conewago Creek and its many tributaries. Most of the southern half drains into the Potomac River through Toms, Middle, Marsh, Rock, and Alloway Creeks and their tributaries (Natural Resources and Conservation Service, 2018). 
Adams County is characterized by more than 100 different kinds of soil, which range widely in texture, natural drainage, depth, slope, and other characteristics. The soils in the South Mountain area are predominantly deep, well drained, and commonly very stony. In this area, slope and stones are major limitations to use of the soils. In the rest of the county the soils have more variable characteristics, including wetness, depth to bedrock, and slope, which are major limitations to their use. The land area is divided as follows: cropland, about $45 \%$; woodland, $30 \%$; pasture, $10 \%$; urban, industrial, commercial, and other land, 15\% (Natural Resources and Conservation Service 2018).

Raven Rock Mountain is a monolith of greenstone granite with numerous locations where the bedrock is exposed on the surface. Forty-five percent of Site $\mathrm{R}$ has slopes in excess of 25 degrees and an additional $45 \%$ of the project area has slopes ranging from 8 to 25 degrees. The soils consist of well drained silt loam heavily included with stone. Subsurface soils are usually encountered within $25 \mathrm{~cm}$ of the surface (Baltimore District 2001). The combination of soil types and slopes are not typically conducive to most habitation, or to agricultural or horticultural activities. Animal husbandry and/or hunting activities may be possible on the shallower sloped areas. The probability of prehistoric archaeological sites being located in these soil and slope types is very low.

\subsection{Prehistoric Context}

Archaeological sites in this area of Pennsylvania have been identified to all prehistoric periods known in the greater Pennsylvania area (Paleo-Indian, Archaic, Transitional and Woodland) (Baltimore District 2001). The environmental and physical diversity in the region would provide prehistoric hunter-gatherer or horticultural peoples with all the resources needed for settlement or survival. The nearest multi-period stratified site, however, is nearly 40 miles distant from the project area (Michels 1969) which indicates that this area was most likely not the epicenter of focused organized political or ceremonial activity. Before European settlement, the area was dominated by Iroquois Confederation affiliated groups such as the Susquehannock, Shawanese, and Delaware (Sanders et al. 1996). Ownership was transferred to Europeans, primarily the Penn family, through treaty and land purchase in the $18^{\text {th }}$ century and was then made available for white settlement (Kline 1985, Baltimore District 2001). 


\subsection{Historic Context}

Raven Rock Mountain is located within the area of the original 1681 land grant that established the colony of Pennsylvania (Kline 1985, Sanders et al. 1996). Early settlement of the colony was focused on the coastal regions. European settlement of the project area began in earnest after Iroquois Confederation ceded the land to William Pitt's descendants in 1723, with some brief disruption of the colonization mid-century due to the French and Indian War (Bloom 1992; Baltimore District 2001).

Early colonization was dominated by German speaking peoples, but by the mid- $18^{\text {th }}$ century the Scotch-Irish had supplanted the earlier settlers (Bloom 1992; Baltimore District 2001). Farmsteads were generally small in size (circa 100 acres) with most production focused on grains and animal fodder. Soils in the project area are not ideal for agriculture and household incomes were usually supplemented through hunting, trapping and fishing activities.

Adams County was established by a subdivision of York County in 1800 with Gettysburg the county seat. The census from that year reports a population for the county of 13,172 (Manson et al. 2018) with 114 of those people recorded as slaves. Nearly half (49\%) of the population was under the age of 15 . The population was predominantly rural as there were only six recorded towns within the county (Bloom 1992). The growth of the county was accelerated with the establishment of a road network. The Nicholson or Nichol's Gap Road was constructed in 1748 as part of the Great Wagon Road from Philadelphia to Pittsburgh (Fry and Jefferson 1753; Rouse 1995). This road follows the path of the current Buchanan Trail and Waynesboro Pike (State Highway 16). Communities sprung up along the road including Fountain Dale, located immediately north of Raven Rock Mountain. The railroad was established in Adams County in 1858 (Baltimore District 2001) at about the same time that the county population had doubled from the 1800 census (Manson et al. 2018).

The area around Raven Rock Mountain saw activity from both the Union and Confederate armies during the Civil War. In 1862 the Confederate cavalry raided parts of western Adams County, including Fairfield (Baltimore District 2001). Fairfield was again raided by Confederates in June 1863 followed by Union troops passing through the town at the end of the month (Coddington 1983; Miller 2013). Two union brigades were marched to Gettysburg on the Waynesboro Pike on 29 June 1863, placing them 
within 0.1 miles of Site R property boundaries. Those troops reported signs of Confederate activity in the area (Coddington 1983). Portions of the Confederate army retreating from the Battle of Gettysburg along the Waynesboro Pike were harassed by Union troops in the vicinity of Site R, culminating in the Battle of Monterey Pass to the east of Site R on the $4^{\text {th }}$ and $5^{\text {th }}$ of July 1863 (Coddington 1983; Miller 2013).

After the Civil War, population growth and economic development slowed. The railroad network was located in the eastern portion of the county and most industrialization occurred there. With the improvement of the transportation network, however, agriculture shifted from subsistence grain crops to cash crops, most notably fruit, as well as animal husbandry (Bloom 1992; Baltimore District 2001). The agricultural products were not processed in the immediate area of Raven Rock Mountain but instead in the eastern portions of the county.

Tourism associated with the Gettysburg battlefield did not significantly impact the western portion of the county. In 1866 a fire started at Mont Alto (on the west side of South Mountain) that spread to a general forest fire over the southern part of South Mountain (Anonymous 1886). This fire significantly damaged the timber and charcoal production in the region further impacting the overall regional economy. In 1884 the HeadLight Copper Mine opened and a history of the county published 2 years later described it as an "important industry" in "permanent form" (Anonymous 1886, p 301). In 1914, however, the mine was described as a $160-\mathrm{ft}$ tunnel that was idle (Stevens et al. 1914).

The modern military presence in the region began in 1926 when the Maryland National Guard established Camp Albert C. Ritchie on the eastern side of Mount Quirauk (Figure 2) (HAER 1968). The site had previously been used by the Buena Vista Ice Company. During World War II, the U.S. Army operated the Military Intelligence Training Center at the camp (Longe et al. 1998). After the war, the camp was briefly returned to the Maryland National Guard before being permanently acquired by the U.S Army in 1948 to support the Alternate Joint Communications Center/Site R (AJCC) at Raven Rock Mountain (Longe et al. 1998). The federal government began purchasing property on Raven Rock Mountain in the early 1950 for the purpose of constructing the current facility. 


\section{Site Revisits and Supplemental Research}

The Baltimore District survey consisted of pedestrian survey, soil probes and shovel test pit excavations (Baltimore District 2001). This survey did not find any prehistoric resources within the Site R boundary. However, it did locate five historic period resources on Site R. These consist of historic

road traces, dry laid rock field walls, two historic archaeological sites and a manmade rock pile (Figure 3). All of these sites were determined to be not eligible for inclusion in the NRHP. ERDC-CERL determined that additional documentation was needed for four of the five resources; the 2001 documentation of the historic road traces was determined to be sufficient. Note that the information presented below is intended to supplement the original report and not replace it.

It was determined that both historic sites A and B as well as the rock walls throughout the installation required additional mapping. After the walls had been mapped, but before the two historic farmsteads were mapped, a snowstorm occurred that made sites A and B inaccessible for safety reasons. Project constraints prevented additional fieldwork. It is suggested but not required that additional mapping of sites A and B occur before any activity on the site that may have adverse effects.

One key resource that was not included in the original report was a 1938 aerial photograph of Raven Rock Mountain. This was found as a hard copy document at RRMC and digitized for this project. Figure 4 shows the locations of roads and discernable buildings from that aerial photograph view along with the 1911 USGS Emmitsburg, Maryland quadrangle map. Additional resources that were used in this report include Light Detection and Ranging (LiDAR) survey data of RRMC provided by RRMC (images from the LiDAR data are not reproduced in this report) and maps of 1952-53 RRMC property boundaries that were located at RRMC and the Adams County Courthouse. 
Figure 3. RRMC showing location of sites and property boundaries.

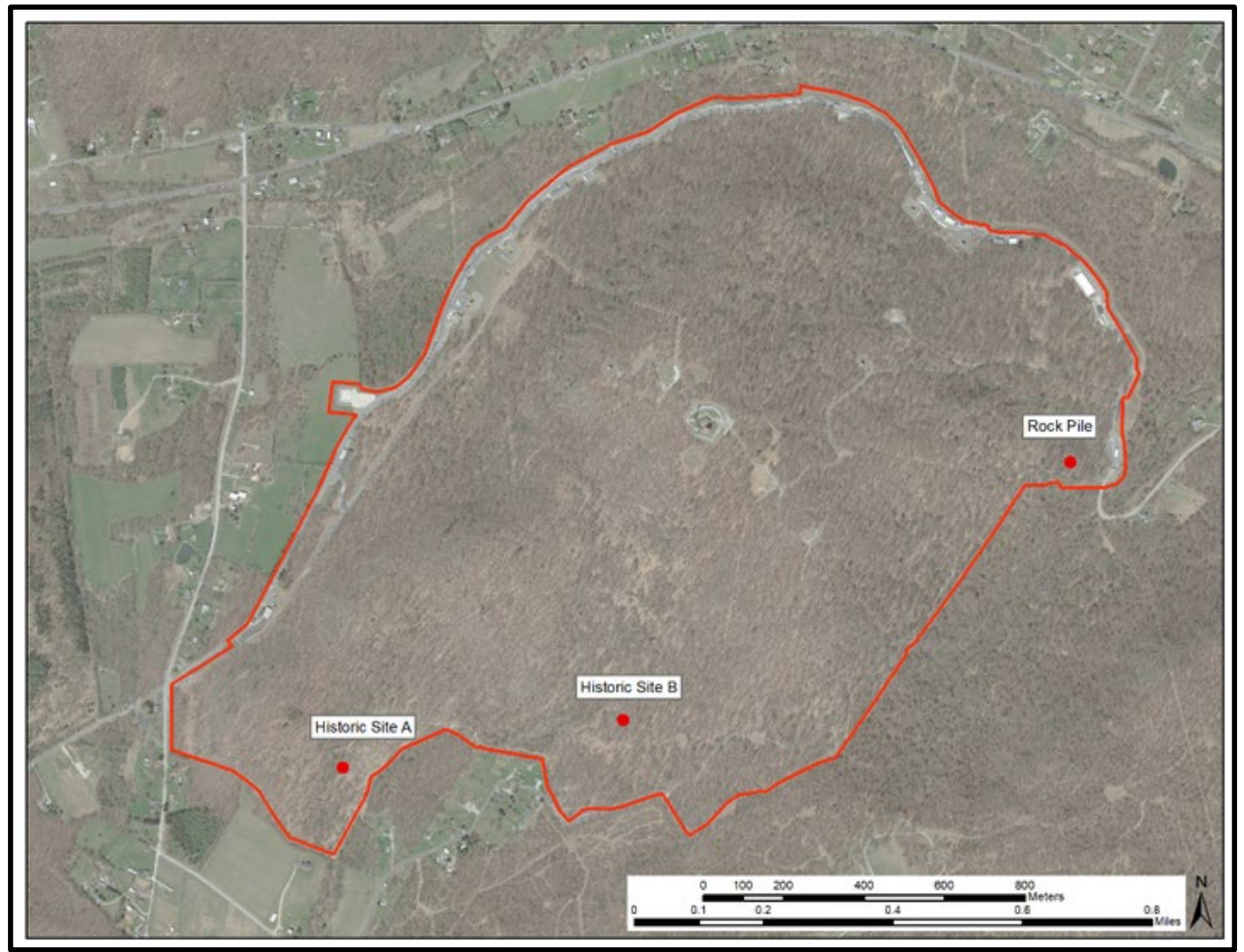

Source: ERDC-CERL (2018).

Figure 4. RRMC with locations of historic buildings and roads.

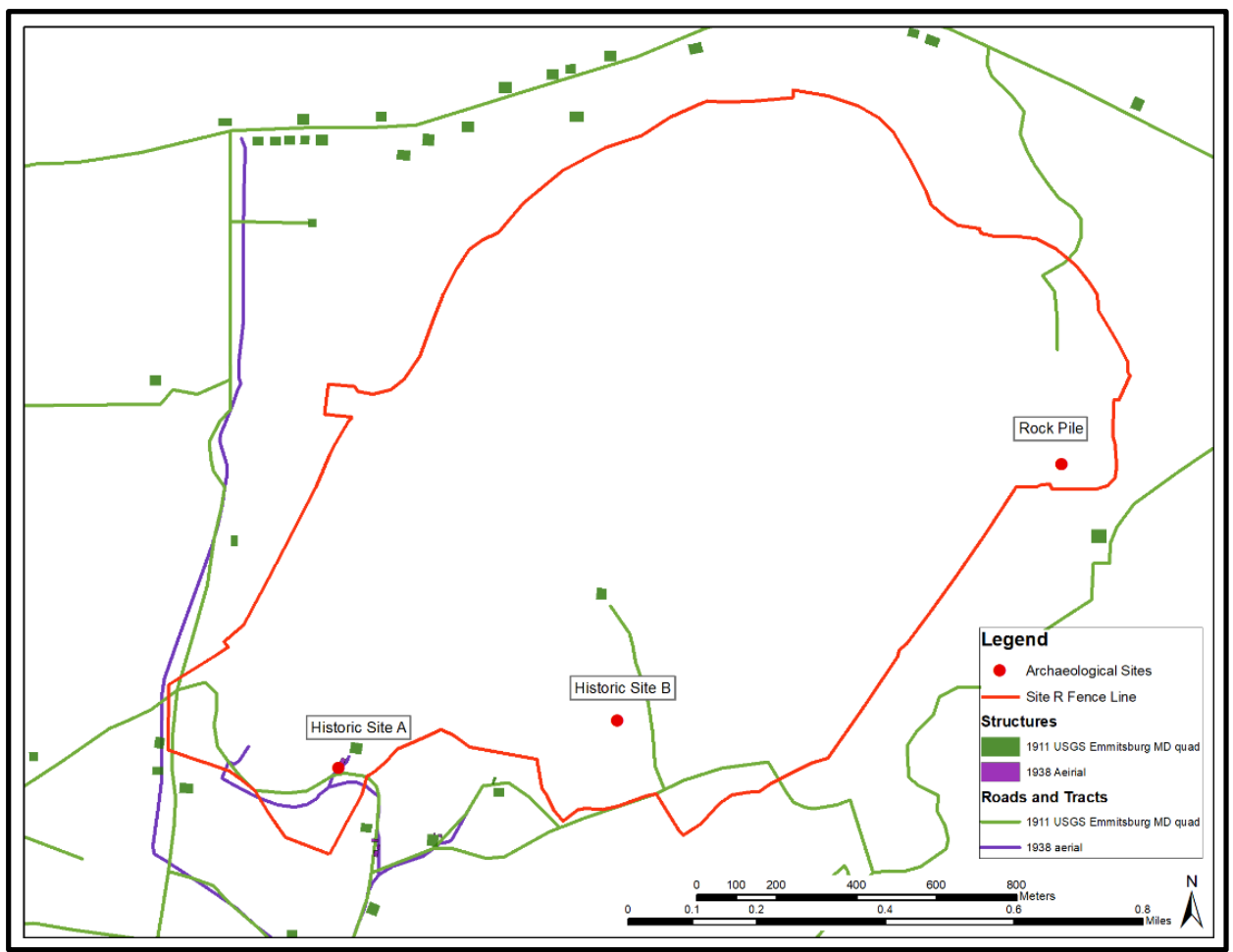

Source: ERDC-CERL (2018). 


\subsection{Historic Site Location A}

The 2001 report described Historic Site Location A (Site Survey No. 36$\mathrm{AD}-440$ ) as the "S. Klien" farmstead based on the Lake (1872) map (Figure 5) and 1911 USGS quadrangle map (Figure 6). It is the opinion of this author that the two structures shown in the 1872 and 1911 maps are not the same structure. While historic maps, including quadrangle maps, can show variance in the location of structures, they usually accurately indicate the side of the road on which structures are located.

Figure 5. Map of the southern portion of RRMC, 1872.

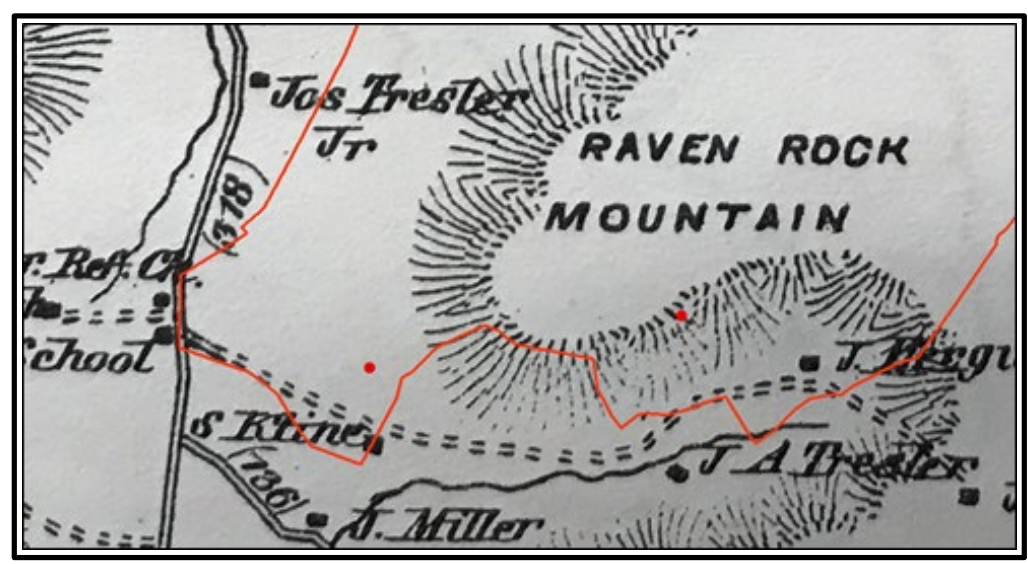

Source: Lake (1872).

Figure 6. Portion of Quadrangle Map and Historic Site A. 191.

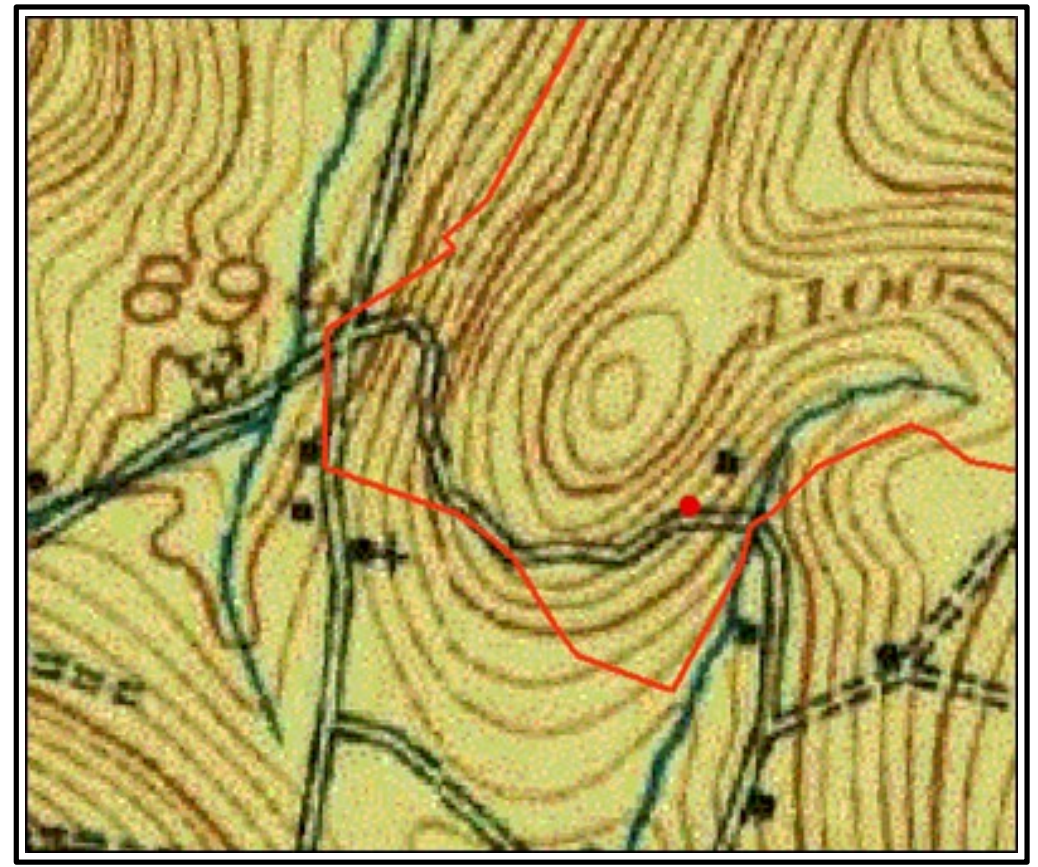

Source: USGS (1911). 
The property ownership maps of RRMC (Figures 7 and 8) show that the site is located on property tract A-113 and under the ownership of Gladhill. Table 1 lists the chain-of-title (documents held at the Adams County Courthouse, Office of the Recorder of Deeds, Gettysburg Pennsylvania.* The chain-of-title search indicates that the designation of the site as the S. Kline property is not accurate. ${ }^{\dagger}$ The property was never owned by a $S$. Kline and no member of the Cline/Kline family owned the property in 1872. An 1858 map of the property appears to be the most accurate as it describes both A. Tressler and J. Miller as residents/owners of properties in the area (Figure 9) (Anonymous 1858). The cemetery on Harbaugh Valley Road, approximately 0.6 miles or $1.0 \mathrm{~km}$ north of the installation main gate contains multiple burials for the Tressler, Miller, Kline/Cline, and Gladhill families.

Adams County records also contain descriptions of the contents of the property in 1911. The land was transferred in a sheriff's deed to the ownership of Grant Gladhill. This deed described the property as "good timberland ... improved with a two story frame house, back barn, hog feed, chicken house and other outbuildings, a never failing spring of water, a young bearing apple orchard and a variety of other fruit" (Sheriff's Deed Book A, p 72, Adams County Courthouse). All regular grantor/grantee deed transfers in the county describe only the boundary lines of the property (usually based on trees, rock walls and streams) and do not include information on improvements to the property.

The 1938 aerial photograph of the site shows well cleared and tended fields along with several structures (Figure 10). Note that the sheriff's deed was only for 85 acres (more or less) but the property maps show more than 1,500 acres in the tract at the time of government purchase in 1952. The field boundaries on the 1938 aerial photograph correspond closely with the property lines on the two deed maps on the west, south, and east sides but both maps show that the property on the north side was well behind the tree line.

\footnotetext{
* The Adams County courthouse only has records for deeds dated after 1800.

† The spellings Kline and Cline appeared to be used interchangeably during the late $19^{\text {th }}$ and early $20^{\text {th }}$ century. Charles P. Cline appeared as Cline in the 1899 Index of Grantees but as Kline in the 1899 Index of Grantors. Both spellings appear on gravestones in the local cemeteries.
} 
Figure 7. Register of Acquisition map, dated 2/12/1953. *

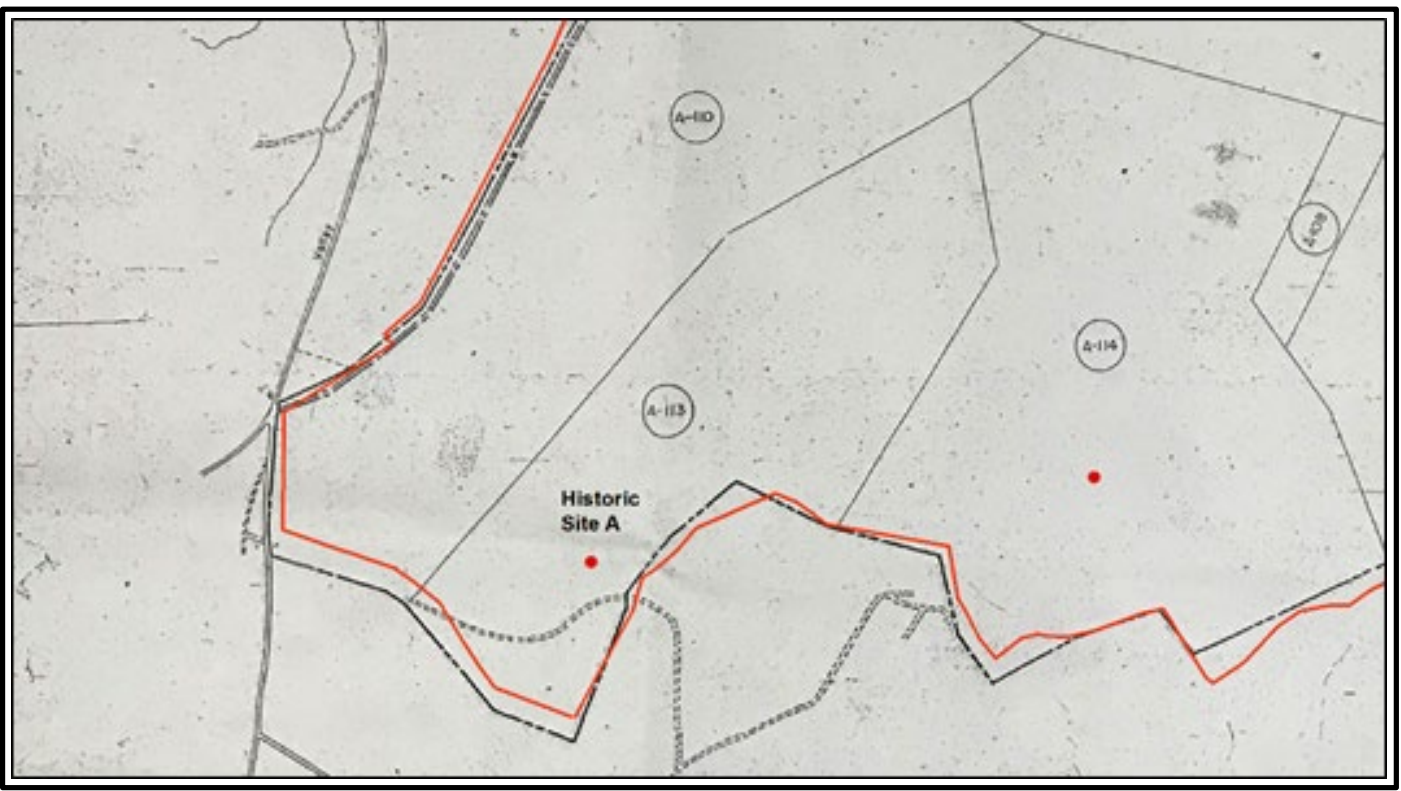

Source: RRMC files

Figure 8. Property map B-18 Liberty and Hamiltonban Township on file at Adams County Courthouse. This map is undated but probably dates to 1952 .

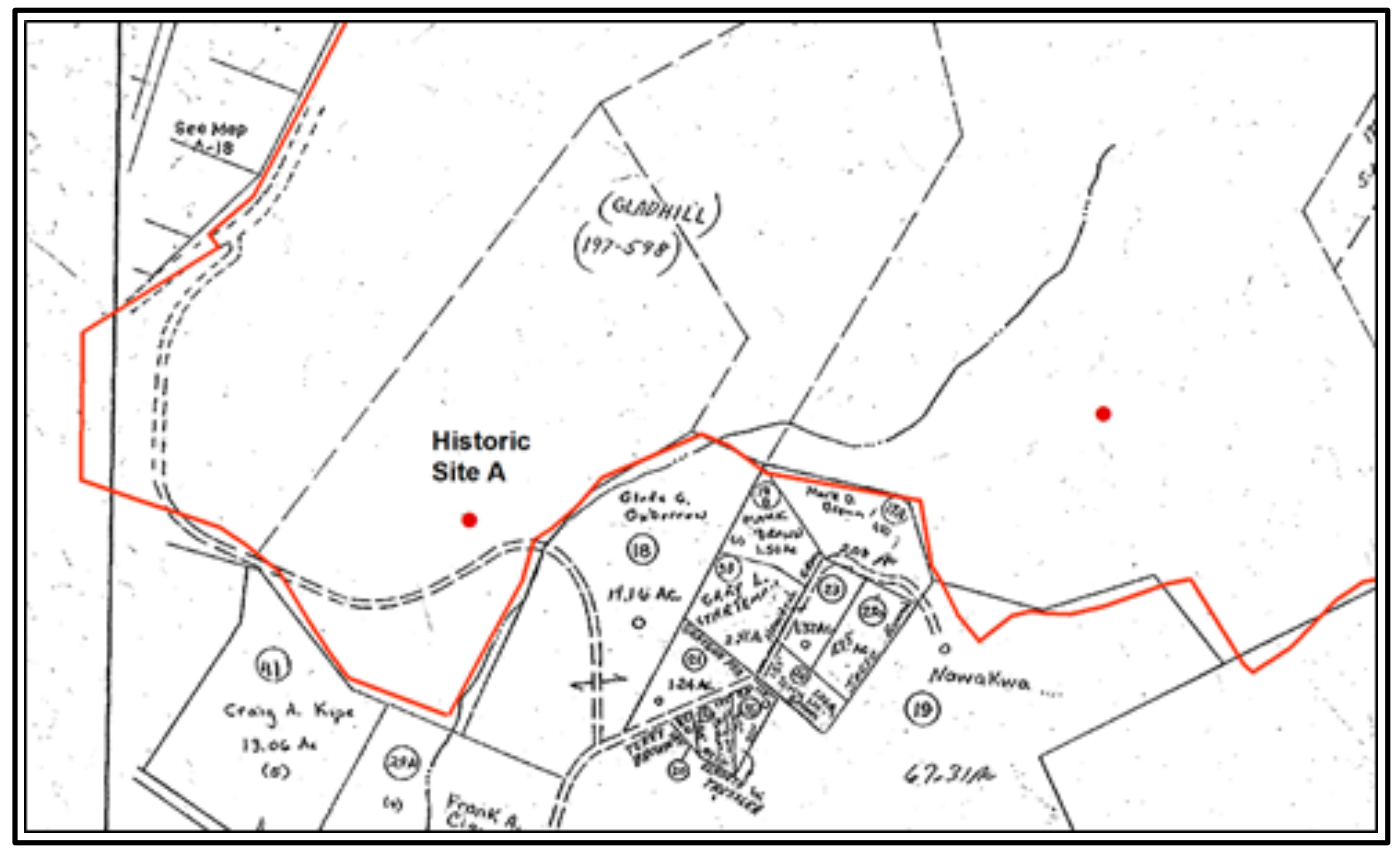

Source: Adams County Courthouse records.

* Property and Acquisition maps are not drawn to survey grade. They are intended as general guides and references with the exact property boundaries points described in the text descriptions for each plot. As a result there is frequently some slight discrepancies in features like roads, rivers and property boundaries. In Figure 7, the red outline of the installation boundaries was taken from a survey grade map. 
Table 1. Chain of Title, Tract A113 (data from Adams County Courthouse, Office of the Recorder of Deeds).

\begin{tabular}{|l|l|l|}
\hline Date & Grantor & Grantee \\
\hline 29 Feb 1952 & Esther Gladhill & U.S. Government \\
\hline 14 May 1921 & Grant E. Gladhill and Emma G. Gladhill & Oscar W. Gladhill and Esther A. Gladhill \\
\hline 28 Aug 1911 & Sheriffs Deed of lands from Charles P. Cline & Grant E. Gladhill and Wife \\
\hline 16 March 1899 & Jacob Miller & Charles P. Cline \\
\hline 31 March 1865 & Adam Tressler and Wife & Jacob Miller \\
\hline 15 Oct 1833 & Sanford Shroder & Adam Tressler \\
\hline
\end{tabular}

Figure 9. 1858 map of project area.

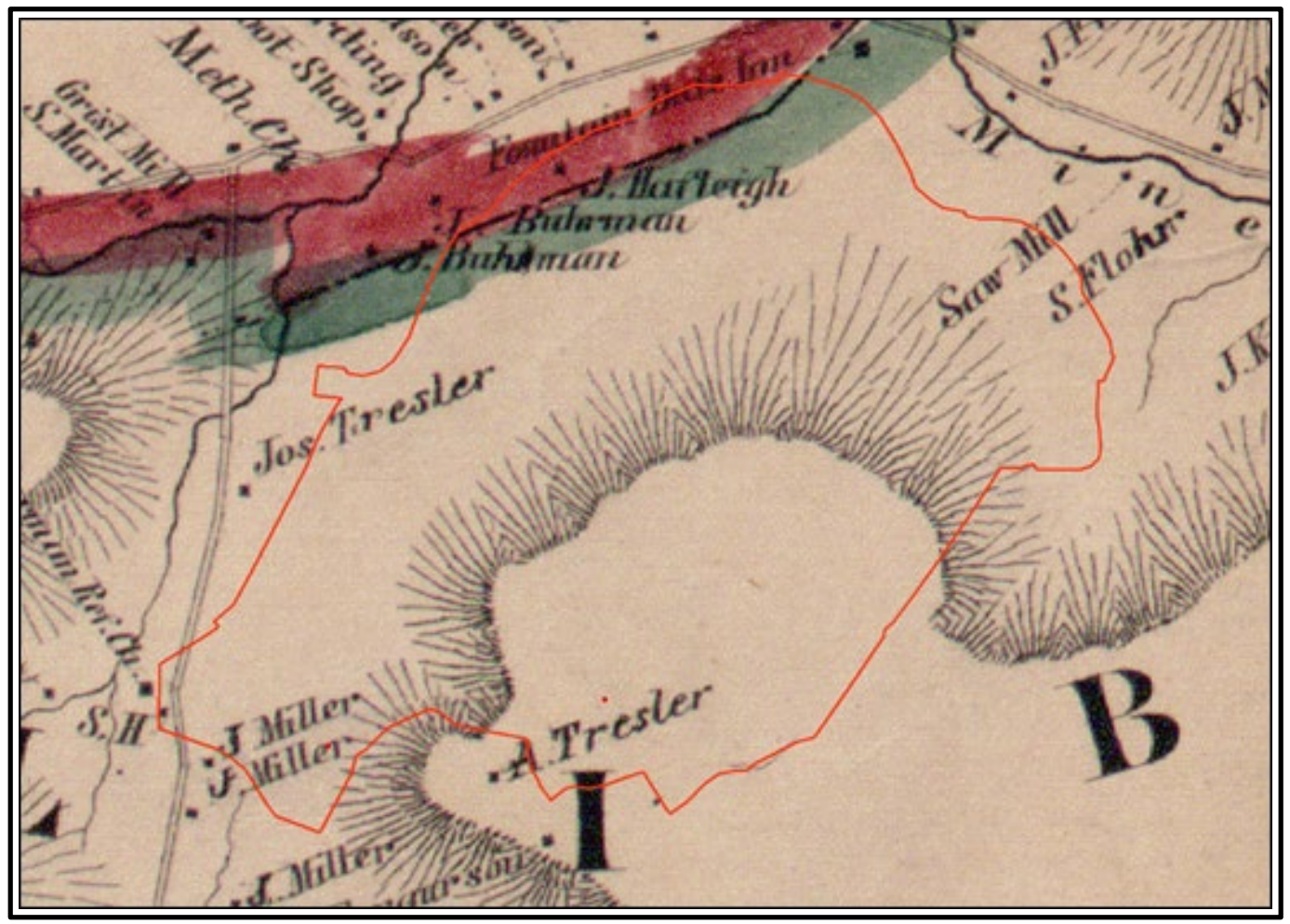

Source: Library of Congress. 
Figure 10. Historic Site A depicted on 1938 aerial map.

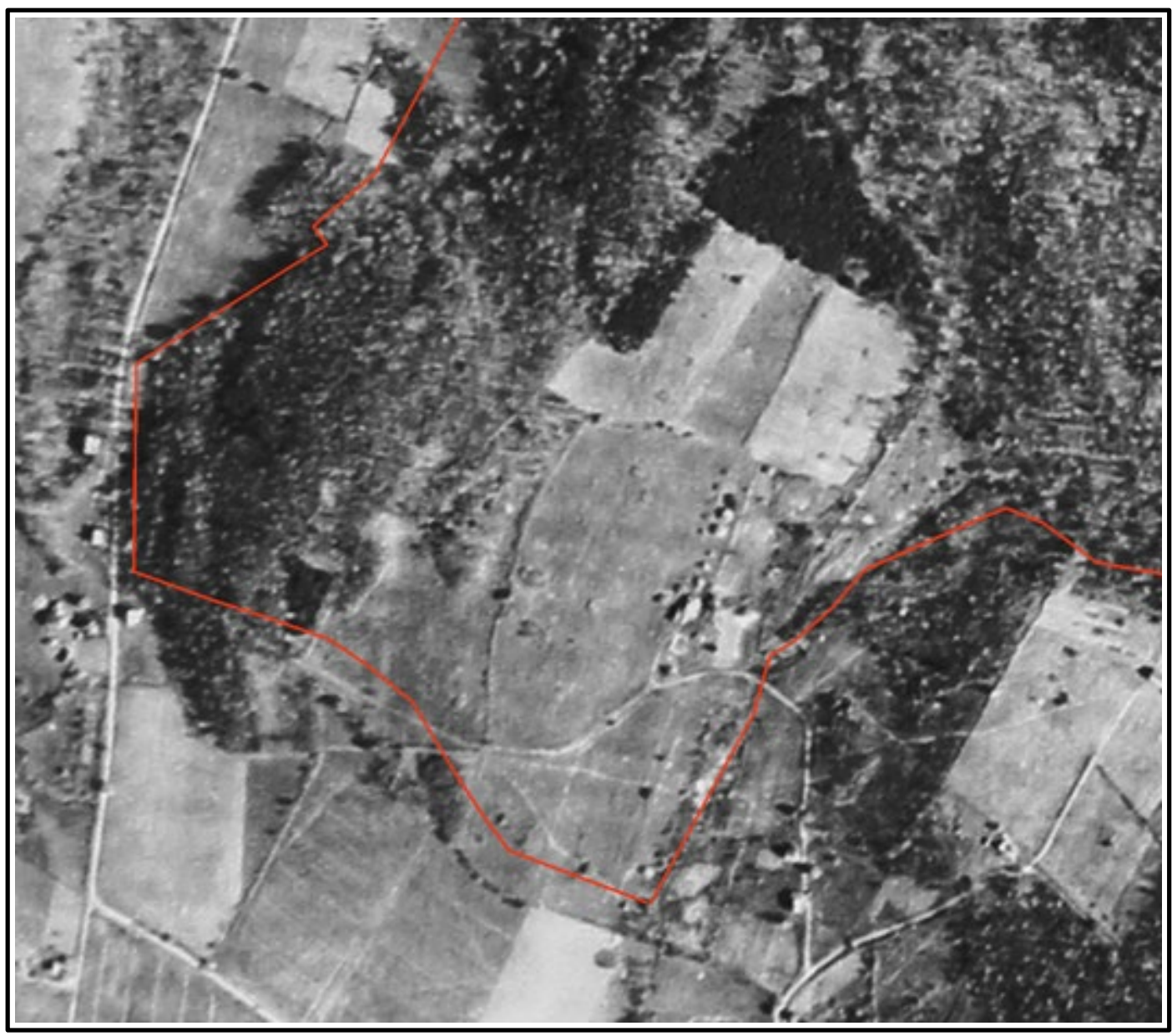

Source: RRMC files.

The 2001 survey mapped the surviving stone foundations on the property in plan and profile (Figure 11). This map did not include any other features at the site. A site visit demonstrated that the road/driveway remnant was still clearly visible. It is hypothesized that feature A3 most likely represents the foundations of the frame house described in the sheriff's deed. This is based on the presence of brick in the foundation. The artifacts recovered in the 2001 shovel test pits in proximity to feature A3 included a significant amount of domestic debris (whiteware, stoneware, redware, milk, and bottle glass) in addition to architectural debris. The other test pits artifacts were dominated by architectural debris. The three-sided feature A1 is possibly the hog feed listed in the sheriff's deed based on the three-sided nature of the structure and the distance from the suspected farmhouse. 
Figure 11. Historic Site A.

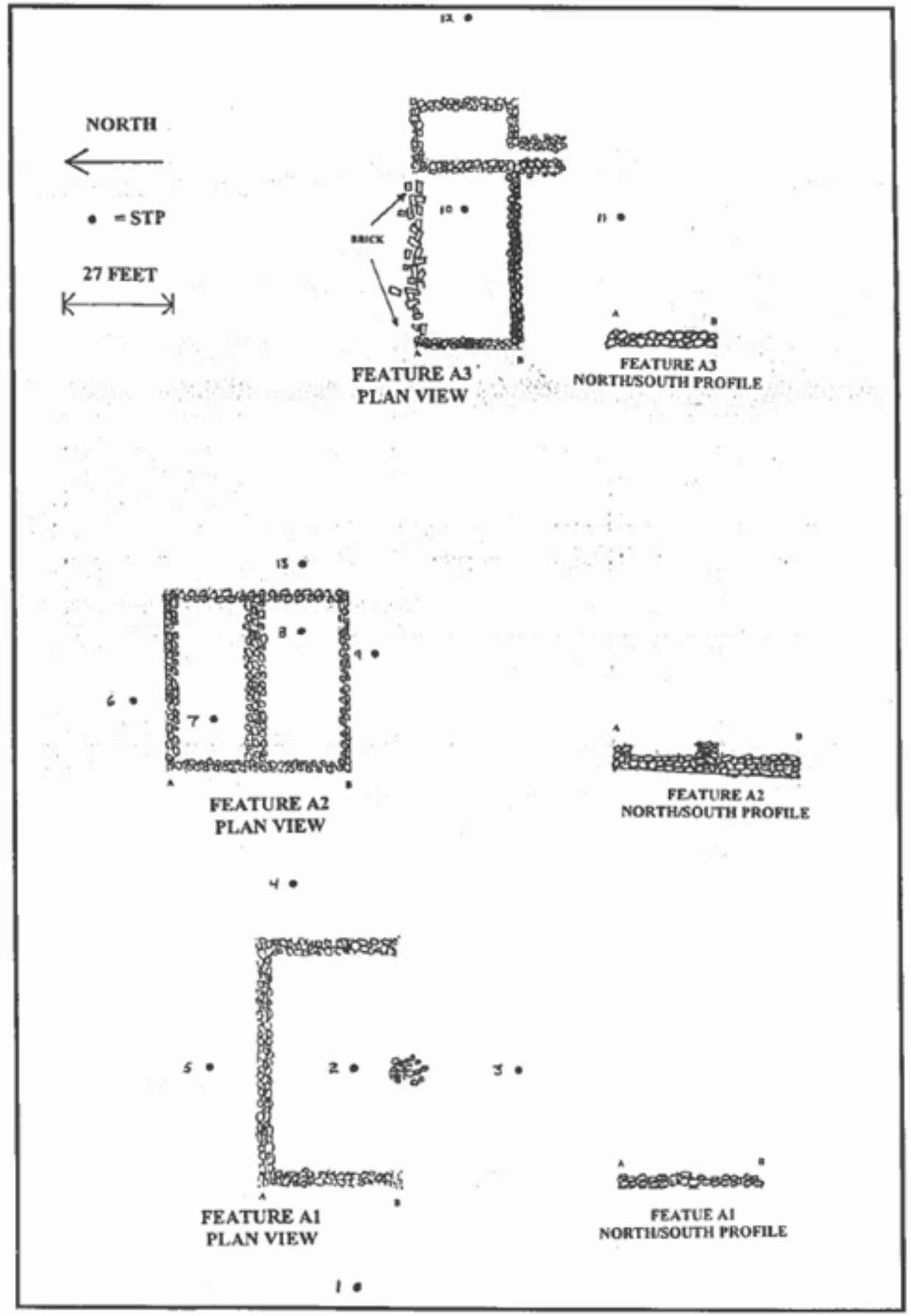

Source: Baltimore District (2001), Fig. 9.

The Baltimore District 2001 report describes this site as not eligible for the inclusion in the NRHP. Nothing in the supplemental research contradicts this determination. No further mitigation efforts are required. It is recommended that in future this site be referred to as the Gladhill farmstead and not the Kline farmstead 


\subsection{Historic Site B}

Historic Site B (Site Survey No. 36-AD-339), which was described in the 2001 survey report as the J. Ferguson property, consisted of a single stone foundation $26 \mathrm{ft} \times 26 \mathrm{ft}$ in size. The Lake (1872) map shows the nearest structure to the site location as belonging to J. Ferguson (Figure 5). Research conducted as part of this work indicates that attribution of this site to Ferguson is incorrect.

The property does not appear on the deed map on file at the Adams County Courthouse (Figure 8), but does appear as tract A114 on the property map held by RRMC (Figure 7). Table 2 lists the chain of title search for this tract. Tract A114 was never owned by the Ferguson family. All deed transfers describe it as being adjacent to the Ferguson property. This farm appears to have been the property of the Martin family for 141 years.

Table 2. Chain of Title, Tract A114 (data from Adams County Courthouse, Office of the Recorder of Deeds).

\begin{tabular}{|l|l|l|}
\hline Date & Grantor & Grantee \\
\hline 23 Jan 1952 & Charles S. Martin & U.S. Government \\
\hline 16 May 1924 & Rebecca Martin & Charles S. Martin \\
\hline 17 April 1901 & Clarence S. Martin & Rebecca Martin \\
\hline 4 June 1900 & D.B. Martin and Wife & Clarence S. Martin \\
\hline 27 March 1851 & John Martin and Wife & David Martin and Wife \\
\hline 14 March 1811 & John Clark & John Martin \\
\hline
\end{tabular}

A structure that may be the foundation found at the site does appear on the 1911 USGS quad map (Figure 12) but this structure is approximately $1000 \mathrm{ft}(300 \mathrm{~m})$ north of the site coordinates. All other historical maps fail to depict this site. The 1938 aerial photograph of the mountain does not show a clearing and there are no structures other than a series of rock walls visible through the trees (Figure 13). The Lake (1872) map does show that an S. Martin owned a house and store in Fountain Dale on the northeast side of Raven Rock Mountain near the junction of the Harbaugh Valley Road and the Waynesboro Turnpike, but none of the owners of tract A114 have a first name that starts with "S" (Figure 14). 
Figure 12. USGS quad map and Historic Site B, 1911.

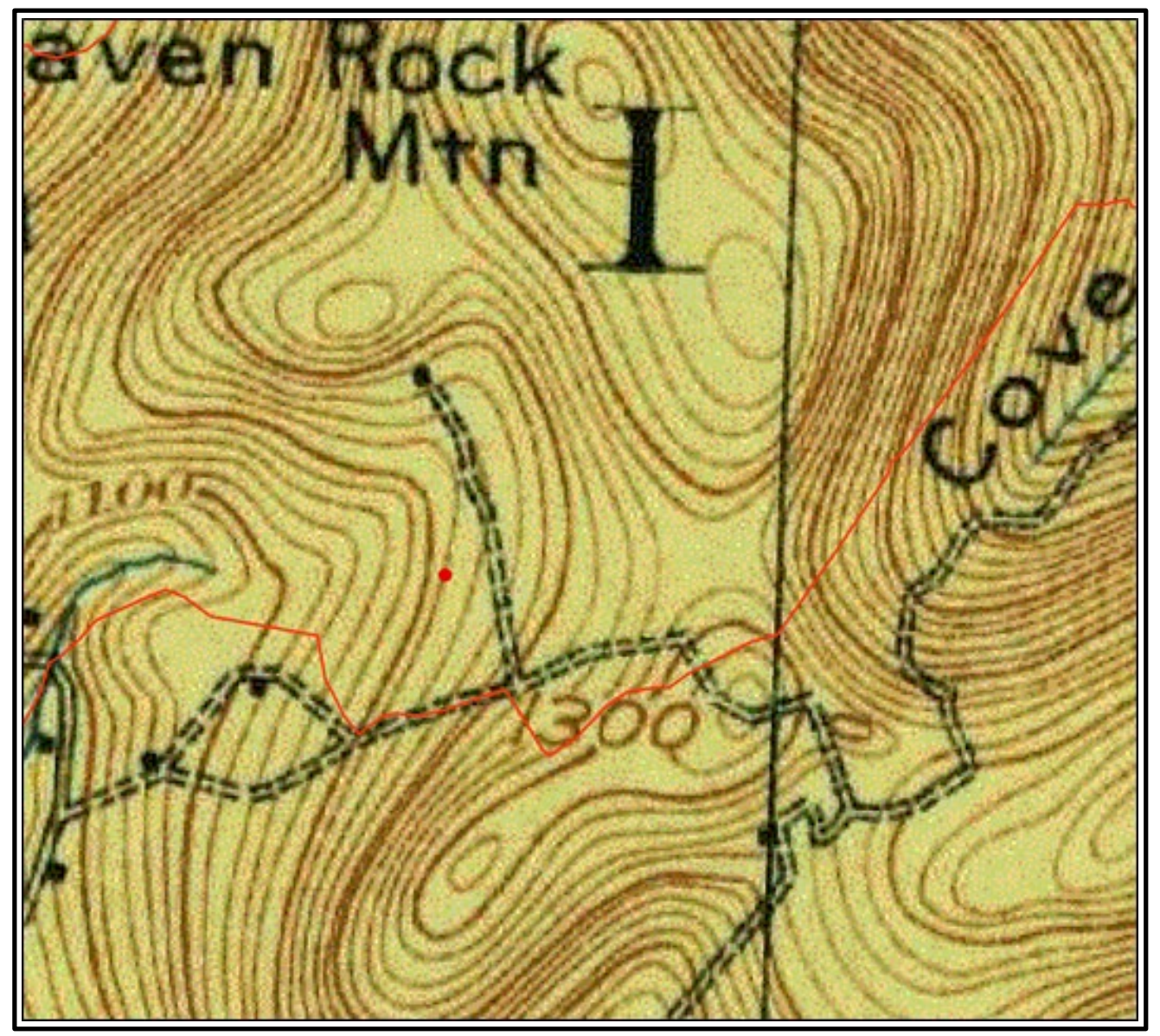

Source: USGS (1911).

Figure 13. Historic Site B depicted on 1938 aerial map.

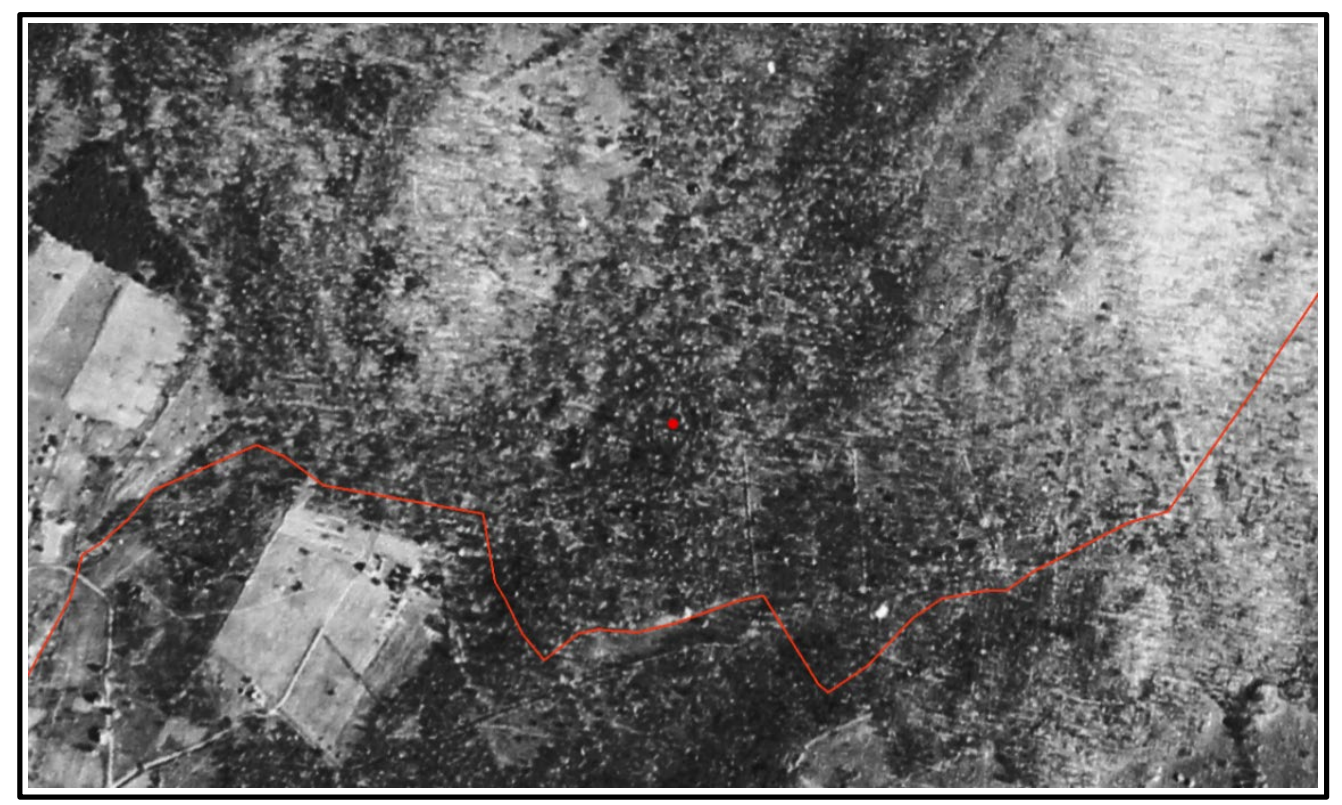

Source: RRMC files. 
Figure 14. 1872 map showing the various Martins in the area of Raven Rock Mountain.

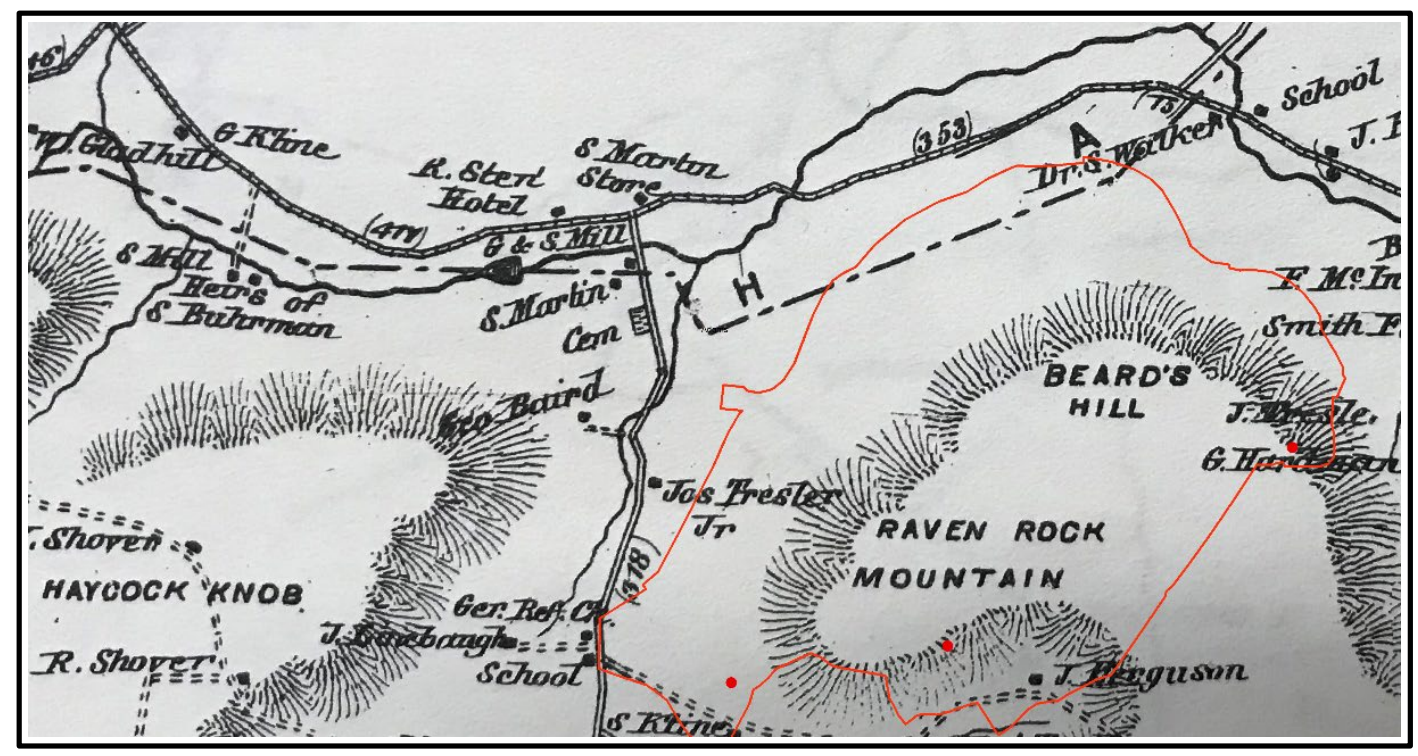

Source: Lake (1872).

The 2001 Survey map shows only a single foundation at the site (Figure 15). The 2001 report also states that RRMC personnel attested that the site had been impacted previously by cutting and filling activities associated with fruit orchard installation and maintenance. Shovel test pits at the site indicate ground disturbance and the introduction of fill material to the site. Some domestic artifacts including whiteware, redware, and bottle glass were found in the test pits. A 2017 ERDC-CERL site visit determined that there were multiple other features at the site. These included a road remnant, a two- or three-sided structure with stone foundations partially cut into a hillside near the mapped foundation and a large, probably artificially flattened area also adjacent to mapped foundation. Weather conditions prevented the ERDC-CERL field crew from mapping this site during available field time. It is recommended, but not required, that these features be mapped before conducting any construction that may have adverse effects. 
Figure 15. Historic Site B.

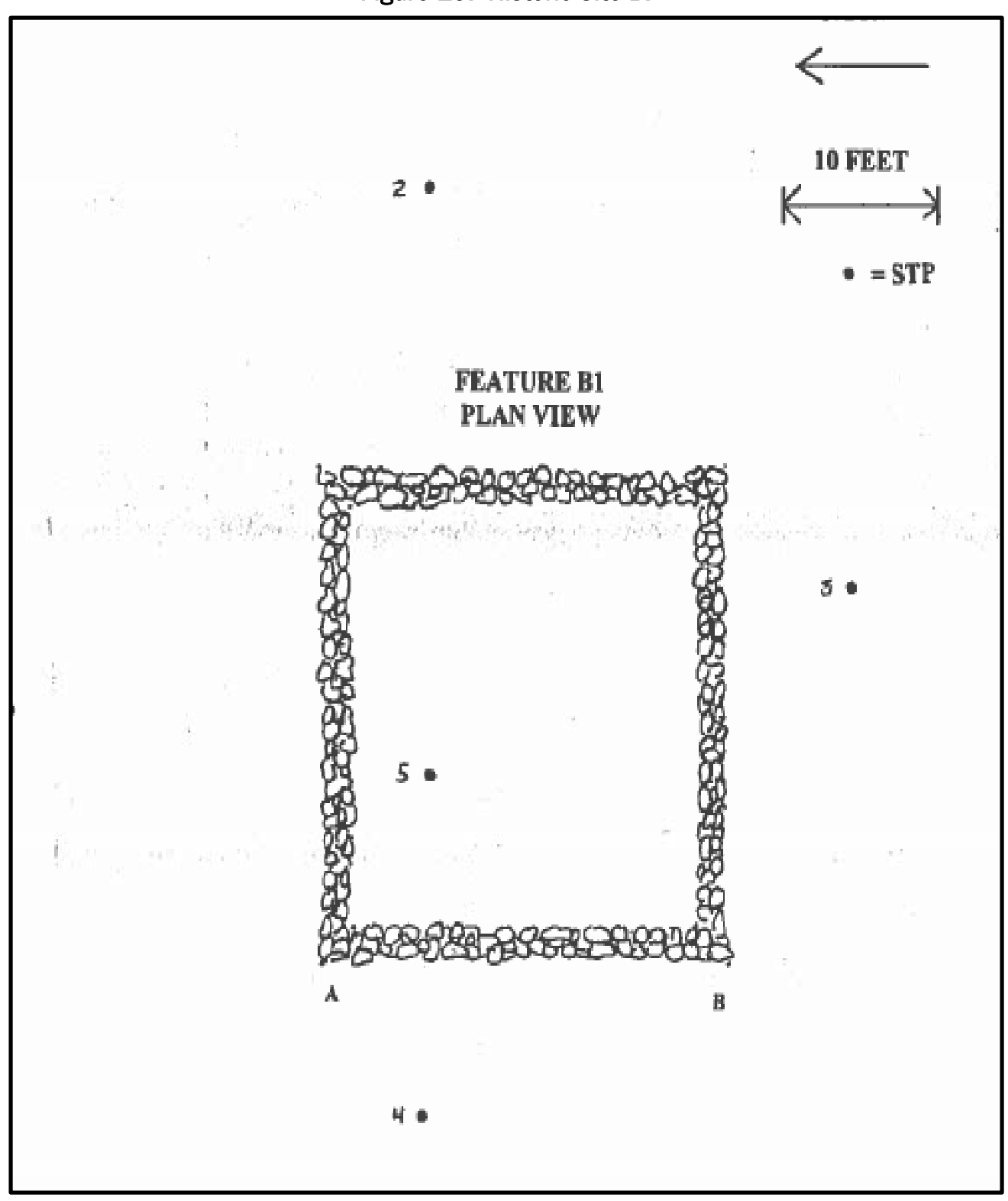

Source: Baltimore District (2001).

The 2001 report finds that this site is not eligible for inclusion in the NRHP. Nothing found in the ERDC-CERL research contradicts that determination. This appears to have been a small site that has been disturbed by subsequent activities at the site. The number and quantity of artifacts reported in the 2001 report are small and the types described are generic $19^{\text {th }}$ and $20^{\text {th }}$ century material. The 1938 aerial photograph indicates that by the mid- $20^{\text {th }}$ century the site was already overgrown with trees and may not even have been occupied or maintained at the time of purchase by the U.S. government. No further mitigation at this site is required. 


\subsection{Rock Walls}

Raven Rock Mountain is crisscrossed with a series of large dry laid rock field walls. These walls were noted in the 2001 report, but were not mapped or further investigated. ERDC-CERL determined that these resources should be mapped. LiDAR and the 1938 aerial map were used to create a GIS shape file of the rock walls and field boundaries (rock walls are visible southeast of Historic Site B in Figure 13). This shape file was then ground-truthed using a decimeter accuracy global positioning system (GPS) mapping device. The rock walls were easily verified and/or adjusted for more accurate positions but the field boundaries were no longer discernable on the landscape. Figure 16 shows the walls in relationship to historic roads and structures and Figure 17 depicts the walls in relationship to property boundaries in the 1952 deed map on file at the Adams County courthouse. There is a close correlation between the rock walls and property boundaries indicating that the walls are historic and tied to property ownership and use.

Rock walls that occur inside of properties may have been used to corral livestock into specific areas. Gettysburg National Battlefield contains many dry rock walls and when consulted, park rangers told the researchers that these walls predated the battle but were used by soldiers as cover from enemy fire. The rangers conveyed that the walls were built "horse high, hog wide" so that horses could not jump over them and hogs could not break through them. The sheriff's deed for the Gladhill farmstead demonstrated that hogs were kept and fruit orchards were cultivated at this farm. It is likely that the rock walls were used to contain the animals that were being fattened up on the orchard windfalls. Driving in the vicinity of Raven Rock Mountain demonstrated that these are indeed a common feature in the historic landscape (Figures 18 and 19).

The 2001 Baltimore District report recommended that the rock walls at RRMC are not eligible for inclusion on the NRHP. The further documentation in this report supports that conclusion. The rock walls have now been mapped. If any construction threatens any existing walls it is suggested, but not required, that the walls be photographed before destruction. No mitigation of these features is required. 
Figure 16. Rock Walls and field boundaries at Raven Rock Mountain.

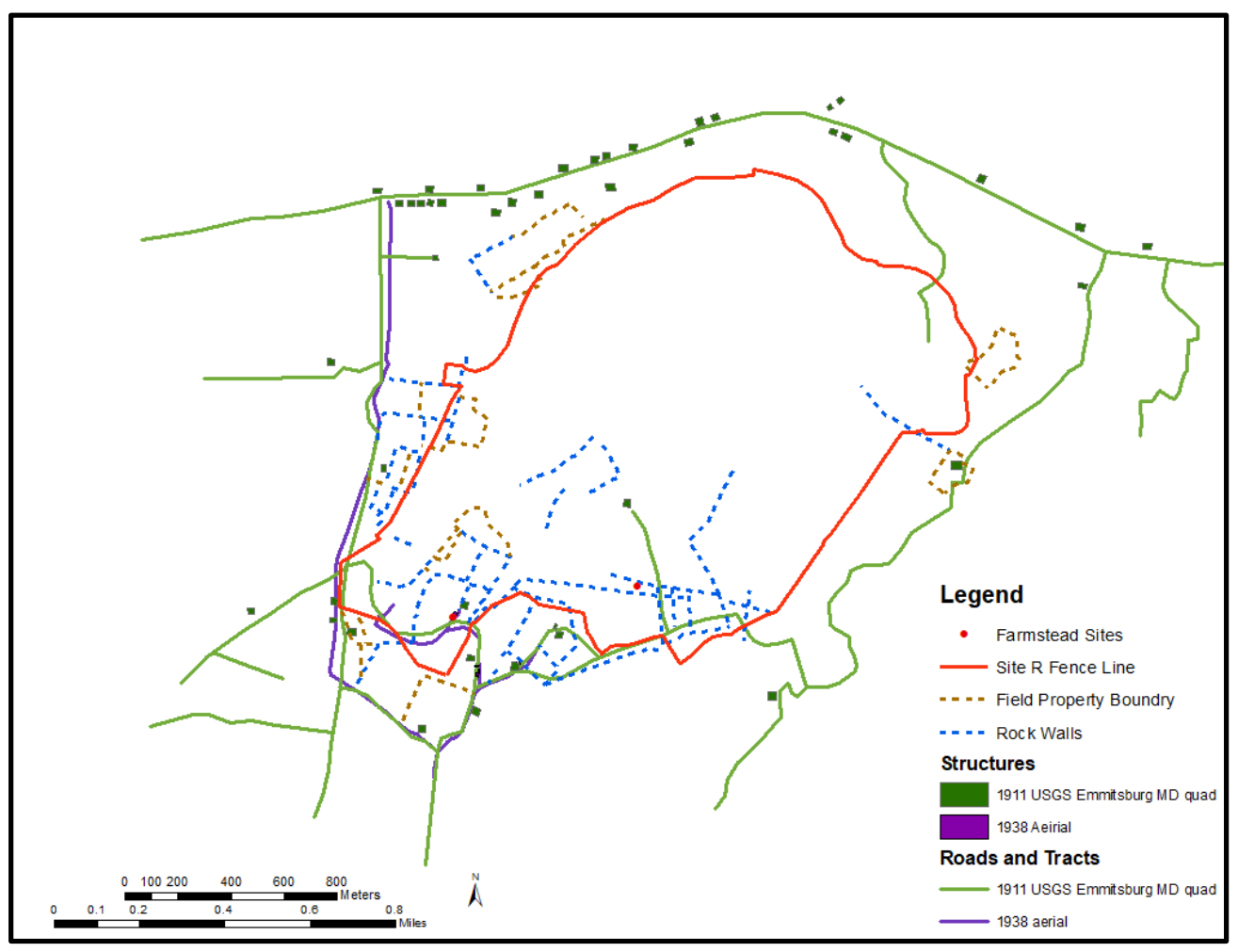

Source: ERDC-CERL (2018).

Figure 17. Rock walls in relationship to 1952 property deed map.

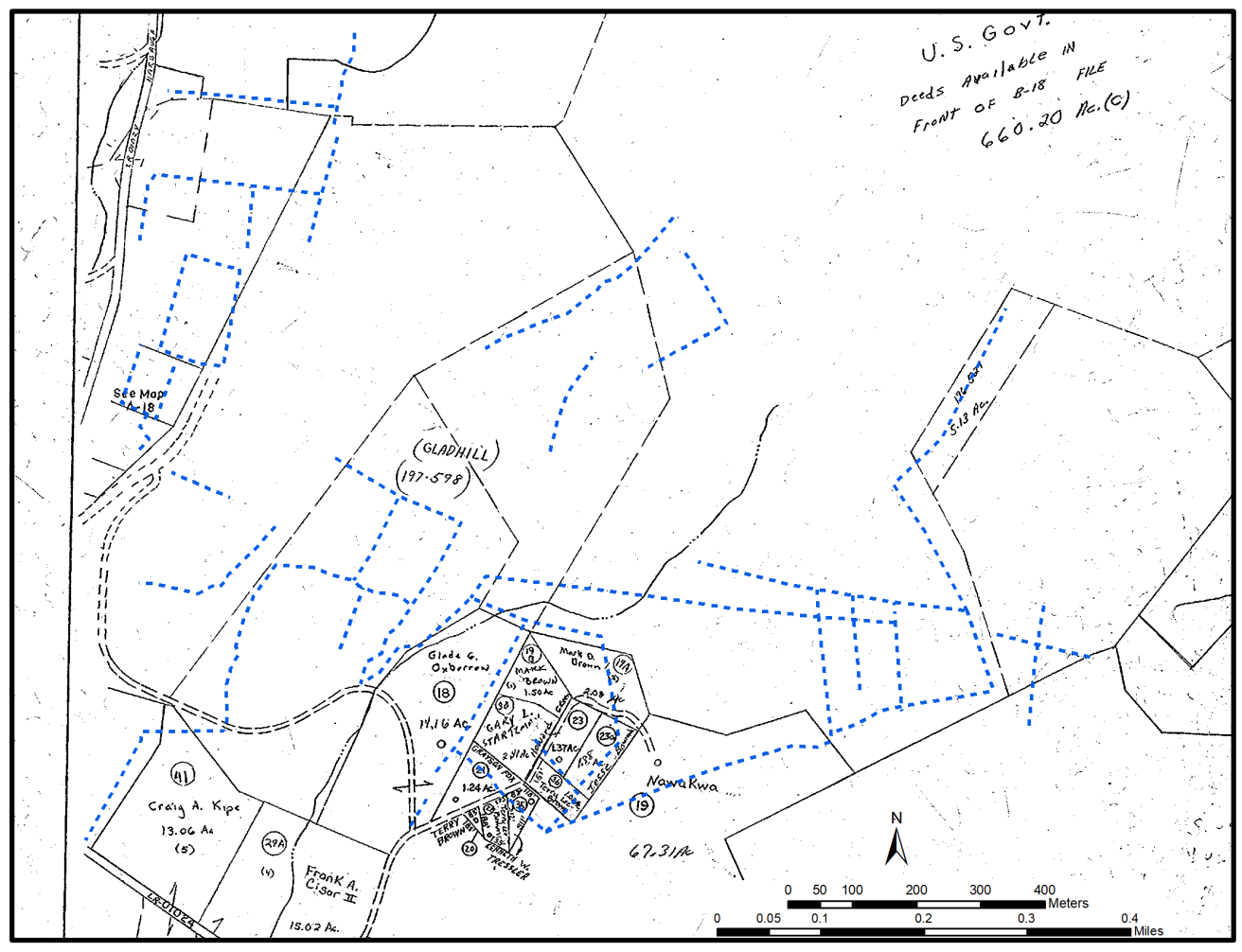

Source: Adams County Courthouse records. 
Figure 18. Rock wall near road in SW Adams County, Pennsylvania.

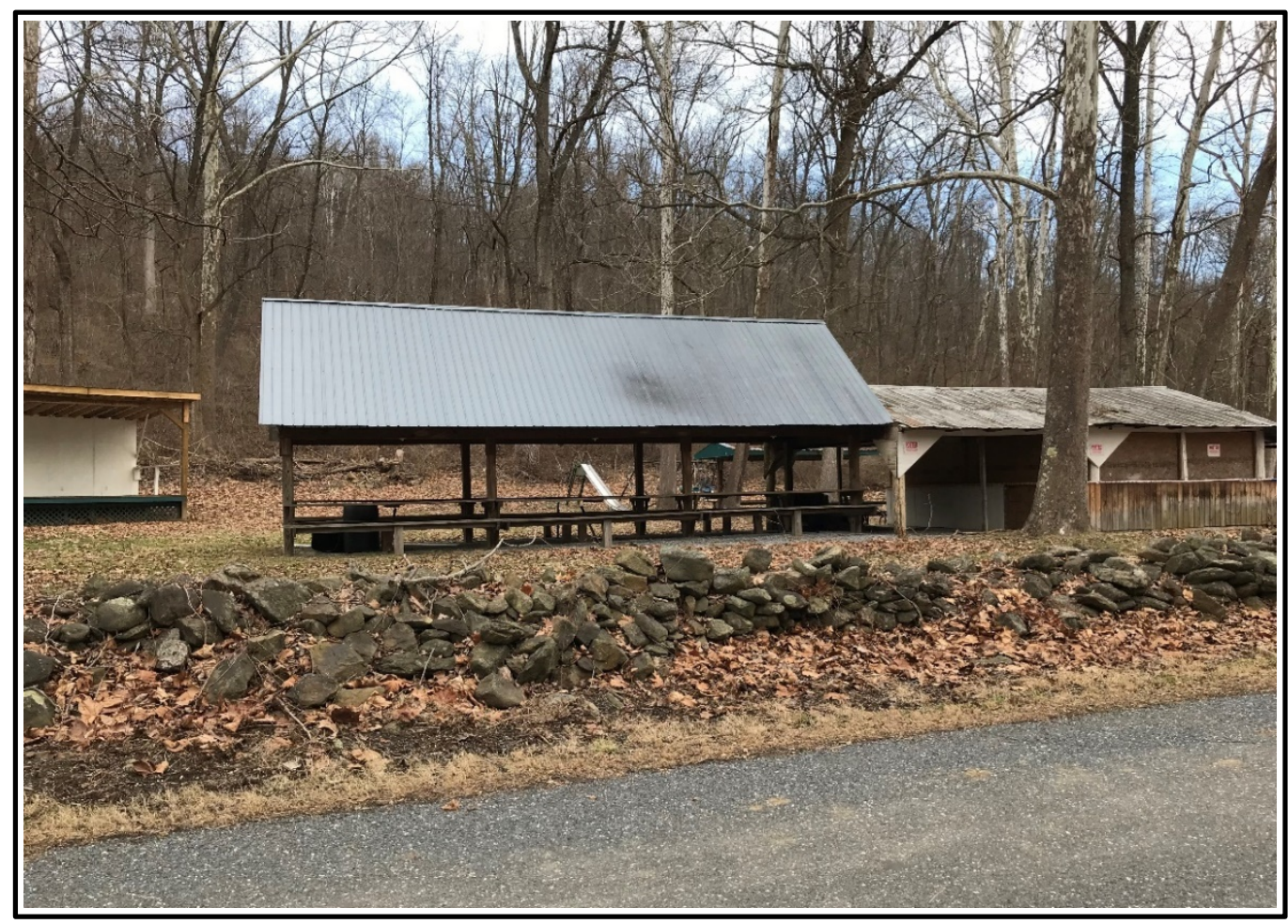

Source: ERDC-CERL (2017).

Figure 19. Rock wall among trees in southwest Adams County, Pennsylvania.

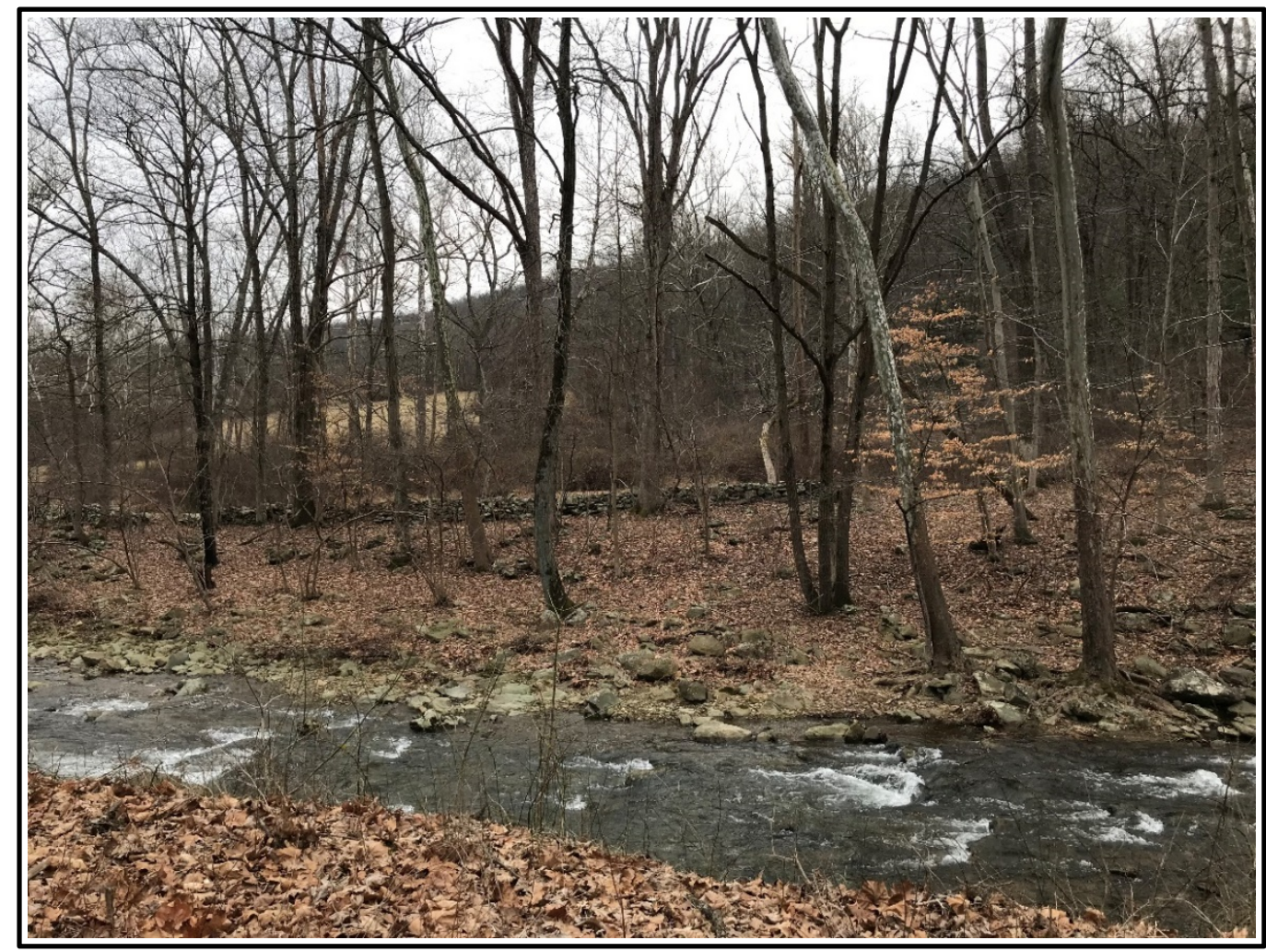

Source: ERDC-CERL (2017). 


\subsection{The Stone Pile}

A manmade stone pile was reported and mapped in the 2001 survey (Figure 18). It is a large, flat topped pile of rocks that is sitting on a rock outcrop and conforms to the outcrop in plan shape. The age and function of this feature is unknown. The 2001 researchers consulted with Civil War historians and eliminated the possibility that this was a military construction (potential gun emplacement) associated with the Battle of Gettysburg based on the lack of sight lines to known military positions from the rock pile (Baltimore District 2001 p 19).

In 2009, however, historians and Cultural Resources Program Management staff from Gettysburg National Military Park examined the features (see letter dated 28 October 2009, Figure 2 in Appendix A, p 34). They noted that the site was situated in such a way as to provide long sight lines though gaps in South Mountain. These historians stated that they could not imagine any other use for these features than possible foundations of "signal stations of some sort, most likely of the Civil War era." The authors of this letter recommended further research of the site to include archival and archaeological investigations

No artifacts have yet been found in association with this feature. The construction of this feature is similar to the dry rock walls that occur on the mountain but this pile does not enclose anything. The steepness of the surrounding hill would make plowing virtually impossible so the pile does not appear to be a field clearing pile. There is a possibility that this could be a Native American structure as cairns are not unknown feature types in prehistoric archaeology. Careful examination of the outcrop by ERDC-CERL researchers did not indicate the presence of any rock art or pictographs.

The author would like to present an alternative hypothesis that this feature was constructed to prevent livestock that might have been foraging on the mountain side from walking over the edge of the stone outcrop. The slope below the feature is much steeper than is indicated in the Figure 20 sketch map and any animal falling over the edge could sustain serious injury that might require the animal to be put down. 
Figure 20. Rock Pile.

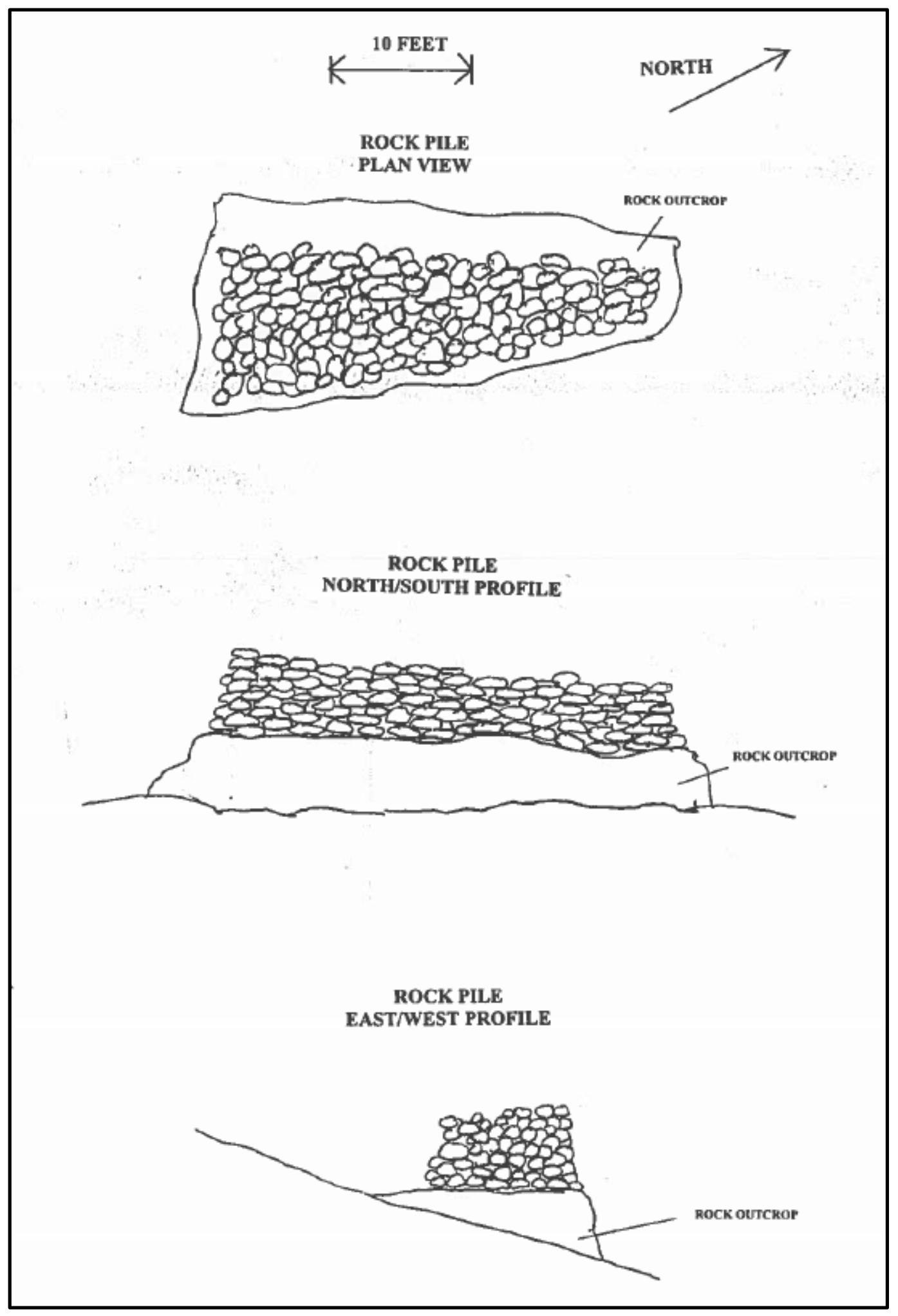

Source: Baltimore District (2001), Fig. 13. 
The Lake (1872) map shows several residences or farmsteads within a few hundred yards of the rock pile (located outside of the RRMC property line) and rock walls are present in the vicinity of the stone pile so it is not unreasonable that animals might have been foraging in the area of the feature.

Because the age and function of this feature could not be determined the original Phase I report determined it to be not eligible and no further mitigation was required (Baltimore District 2001). ERDC-CERL's opinion is that this eligibility determination is incorrect specifically because we do not know the age and function of the feature. It is recommended that the site be determined potentially eligible to the NRHP. In 2010, the Commonwealth of Pennsylvania Bureau for Historic Preservation stated that, if the site were to be impacted, then the function and eligibility of the site should be determined with additional research (see letter dated June 1, 2010 in attached Appendix).

The site should be avoided. The recommended avoidance area is the stone pile and all land 25 meters ( $80 \mathrm{ft}$ ) in any direction of the pile. If any planned construction or other ground disturbance activity has the potential to impact the avoidance area, then additional investigation should be conducted to determine completely the age and function of this site. Additional care should be taken that any ground disturbance activity down slope of the site should not undermine the stability of the avoidance area. Future investigations of the site may include archival research, 3-D scanning of the feature, metal detection surveys, and/or controlled excavation of a portion of the feature or surround area to determine this features age and function. 


\section{Determination of Eligibility for the NRHP}

NRHP eligibility is determined if a property possesses historic significance and sufficient integrity to represent that significance.

\subsection{Significance}

Significance is defined as the meaning or value ascribed to a cultural landscape based on the NRHP criteria for evaluation. There are four eligibility criteria against which site significance is evaluated for the NRHP. These four criteria are described in National Park Service Bulletin No. 15, How to Apply the National Register Criteria for Evaluation (NPS 1997a, p 11).

- Criterion A applies to properties associated with events that have made significant contributions to the broad patterns of history.

- Criterion B applies to properties associated with the lives of persons significant in our past.

- Criterion $\mathrm{C}$ applies to properties embodying the distinctive characteristics of a type, period, or method of construction; possessing high artistic values; or representing a significant and distinguishable entity, the components of which may lack individual distinction.

- Criterion D applies to properties that have yielded or are likely to yield, information important to prehistory or history.

\subsection{Integrity}

Integrity is defined as the authenticity of a property's identity, evinced by the survival of the site's physical characteristics. Archaeological integrity describes the quality of information and level of preservation for an archaeological site, district, or assemblage. Good archaeological integrity is ascribed to properties that are relatively intact and complete, and that have not been significantly impacted by later activities or natural processes. Poor integrity indicates that the site has been disturbed through the actions of people (such as ground disturbances or artifact collecting) or by natural processes such as erosion. The archaeological record, however, is complex; any determination of integrity must be made within the historical and modern context of the property. 
Archaeological integrity is evaluated on seven aspects. These aspects of integrity are fully described in Bulletin No. 15 (NPS 1997a, p 44-49) and are summarized as

- Location: the place where the item was constructed/manufactured or a historic event occurred;

- Design: the elements that constitute the form, plan, space, structure and style of a property;

- Setting: the physical environment of a property;

- Materials: the physical elements or parts that were combined or deposited in a pattern or manner to form an archaeological property;

- Workmanship: the evidence of the labor and skill of a culture or people;

- Feeling: the expression of the aesthetic or historic sense of a particular period of the past; and

- Association: the direct link between an important historic event or person and a historic property. (Under Criterion D, the link is measured in the strength of association between data and important research questions.)

Archaeological properties rarely have undisturbed cultural deposits. Longterm occupation or repeated revisiting of sites creates complex stratigraphy. Features visible above ground and the distribution of artifacts may be used as evidence of below-ground integrity. For properties considered eligible under Criterion $\mathrm{D}$, integrity relates directly to the ability of the site to provide information to the research questions defined within the archaeologist's or installation's research design. In general, however, archaeological integrity is demonstrated by the presence of spatial patterning of artifacts or features that represent differential uses or activities and the lack of serious disturbance to the property's archeological deposits (NPS 1997a, p 46-49).

\subsection{Findings at Raven Rock Mountain Complex Site $\mathbf{R}$}

Five sites have been located at RRMC Site R. The NRHP evaluations for each site follow:

1. Historic road traces were located at various locations on the installation. Historic roads are a common feature type throughout the region. The location of the roads has been documented with historic maps. There is little probability that further archaeological investigation of these roads will yield any additional information about the inhabitants of the region. These features are not eligible for inclusion in the NRHP. 
2. Historic Site A - 36-AD-440, the Gladhill site (previously called the Kline Site). This site is a $19^{\text {th }}-20^{\text {th }}$ century farmstead. The primary features of the site are foundation remnants of three square structures. Farmsteads of this type are present throughout the region. Standing, still occupied, farmsteads from this period are present outside the installation at a distance of less than 2 miles from this site. Phase 1 investigations of the site conducted in 2001 did not recover any artifact type not typically seen at habitation sites from this period. Archival research did not indicate that any person of historical significance or any historically significant event is associated with this farmstead. There is little probability that further archaeological investigation of this site will yield any additional information about the inhabitants of the region. This site is not eligible for inclusion in the NRHP.

3. Historic Site B - 36-AD-339, the Martin site (previously called the Ferguson Site). This site is similar in age and function but smaller than historic site A. The primary feature of the site is a single square foundation remnant. Phase 1 investigations of the site conducted in 2001 did not recover any artifact type not typically seen at sites of this type, but did recover evidence that the site had been previously impacted by ground disturbance activity that had degraded the integrity of the site Oral history at RRMC also indicated previous activities with adverse effects occurred at this site. Historical research also indicated that the site may have been unoccupied for many years before U.S. Army purchase of the property, reducing the possible occupation span of the site. Archival research did not indicate that any person of historical significance or any historically significant event is associated with this farmstead. There is little probability that further archaeological investigation of this site will yield any additional information about the inhabitants of the region. This site is not eligible for inclusion in the NRHP.

4. The Rock Walls. Dry rock walls are a common feature type in the region. Rock walls of very similar size and construction technique were observed in a state of good maintenance on private property immediately outside of the installation fence line. The location of the rock walls was mapped using historic aerial photographs and LiDAR data and then ground truthed with surface survey and GPS data collection. Some of the rock walls on the property have already been impacted by construction activity on RRMC, decreasing the integrity of these features. There is little probability that further archaeological investigation of these walls will yield any additional information about the inhabitants of the region. This site is not eligible for inclusion in the NRHP. 
5. The Stone Pile near the East Gate. The age and function of this feature has not been determined. The site appears to have good integrity with no evidence of recent disturbance of the pile or the ground around it. If the site is determined to be related the Civil War Battle of Gettysburg, it may have significance under criteria A, B or D. If the site is determined to be Native American burial or spiritual site, then it would fall under the protection of the Native American Graves and Repatriation Act. Until such time as the true nature of the site can be determined, it should be considered potentially eligible for inclusion on the NRHP. An avoidance area that includes the stone pile and all land within 25 meters ( $80 \mathrm{ft}$ ) in any direction from the site should be established. Ground disturbance activity including construction activity should not be conducted in the avoidance area until further investigation has been conducted to definitively determine the age and function of the site. 


\section{Final Recommendations for Eligibility and Conclusion}

The 2001 Baltimore District survey of RRMC identified no prehistoric and five historic archaeological resources on the property. Baltimore District concluded that none of these sites were eligible or potentially eligible for inclusion to the NRHP.

After site revisits and additional historic and archival research, ERDCCERL recommends the following.

1. Historic road traces. ERDC-CERL concurs with their findings that these features are not eligible for the NRHP and that no further documentation or mitigation is required.

2. Historic Site A - 36-AD-440, the Gladhill site. ERDC-CERL concurs that this site is not eligible for the NRHP and that no further documentation or mitigation is required.

3. Historic Site B - 36-AD-339, the Martin site. ERDC-CERL concurs that this site is not eligible for the NRHP and that no further documentation or mitigation is required.

4. The Rock Walls. ERDC-CERL concurs that these features are not eligible for the NRHP and that no further documentation or mitigation is required.

5. The Stone Pile. ERDC-CERL does not concur with Baltimore District's conclusion that this site is not eligible for the NRHP. Until the age and function of this feature can be determined it should be considered potentially eligible for the NRHP. Activity with adverse effects on the site should not occur within 25 meters ( $80 \mathrm{ft}$ ) of the feature. Potential future lines of inquiry for this feature include, but are not limited to, metal detector surveys, 3-D scanning, and/or controlled excavation of a portion of the feature or surrounding areas to determine if something is buried beneath it or to locate diagnostic artifacts. 


\section{Bibliography}

\section{Cited works}

Anonymous. 1858. Map of Adams County, PA. Map of unknown author or publisher. Kept on file by the Library of Congress (LOC). LOC identification number 2012592149.

Anonymous. 1886. History of Cumberland and Adams Counties Pennsylvania. Chicago: Warner, Beers and Co.

Baltimore District (U.S. Army Corps of Engineers, Baltimore District) 2001. Phase I Cultural Resource Investigation: Alternative Joint Communication Center Site $R$, Raven Rock Mountain. Report submitted to the U.S. Army Garrison Fort Detrick, Director of Installation Service, Environmental Management Office.

Bloom, Robert L. 1992. A History of Adams County, Pennsylvania, 1700-19oo. Gettysburg, PA: Adams County Historical Society.

Coddington, Edwin B. 1983. The Gettysburg Campaign: A Study in Command. Dayton $\mathrm{OH}$ : Morningside Bookshop.

HAER (Historic American Engineering Record). 1968. "U.S. Army Garrison Fort Ritchie, Upper Lake Dame, Fort Ritchie Military Reservation, Cascade, Washington County, MD.” HAER No. MD-104. Philadelphia, PA: HAER, National Park Service, Northeast Region, Philadelphia Support Office. LOC Call No. Library of Congress as HAER MD,22-CASC,1-. https://www.loc.gov/item/md1387/.

Kline, Joel L. 1985. An Archaeological Overview and Management Plan for the Site R. Report submitted to the National Park Service, Philadelphia, PA.

Lake, D.J. 1872. Map of Adams County, Pennsylvania. Philadelphia, PA: I. W. Field and Company.

Longe, T., J. Helstowski, R. Chuang, D. Johnston, G. McKown, K. Mason, R. Rikramanayake, and C. Troxell. 1998. Fort Ritchie Base Realignment and Closure (BRAC) Cleanup Plan (BCP), Version II. Aberdeen Proving Ground, MD: U.S. Army Environmental Center. https://apps.dtic.mil/dtic/tr/fulltext/u2/a348918.pdf.

Michels, Joseph W. 1969. "Settlement Pattern and Demography at Sheep Rock Shelter: Their Role in Cultural Contact” Southwestern Journal of Anthropology, Vol 25, No $1,1969$.

Miller, John A. 2013. A Midnight Battle Along the Mason-Dixon Line: A Civil War 15o th Commemorative Handbook of the Battle of Monterey Pass. Chambersburg, PA: Franklin County Visitors Bureau.

NPS. 1997a. National Register Bulletin \#15: How to Apply the National Register Criteria for Evaluation. Washington, DC: U.S. Department of the Interior, 1997 (rev.). 
. 1997b. National Register Bulletin \#16A: How to Complete the National Register Registration Form. Washington, DC: U.S. Department of the Interior, National Park Service, 1997.

. 1999. National Register Bulletin: How to Prepare National Historic Landmark Nominations. Washington, DC: U.S. Department of the Interior, National Park Service, 1999.

Stevens, Horace Jared, Walter Harvey Weed, Walter Garfield Neale, Lenox Hawes Rand, Edward Barney Sturgis, Joseph Zimmerman (editors). 1914. Mines Register: Successor to the Mines Handbook and the Copper Handbook. Vol XI. Houghton, MI: Walter Harvey Weed.

USGS (U.S. Department of the Interior Geologic Survey). 1911. "Maryland-Pennsylvania Hagerstown Quadrangle 7.5 Minute Quadrangle.”

\section{Uncited works}

Mason, Steven, Jonathan Schroeder, David Van Riper, and Steven Ruggles. 2018. "IPUMS National Historical Geographic Information System [Database]" Minneapolis: University of Minnesota, 2018. https://www.nhgis.org/

USDA NRCS (U.S. Department of Agriculture, Natural Resources Conservation Service). 2018. "Web Soil Survey." https://websoilsurvey.nrcs.usda.gov/app/WebSoilSurvey.aspx.

\section{Archival resources}

\section{Adams County Courthouse, Gettysburg, Pennsylvania.}

Land Records Adams County, Pennsylvania, 1800-Current.

Property map of land property lines and parcel number for Raven Rock Mountain, Undated but probably circa 1951.

\section{Raven Rock Mountain Complex Site R.}

Aerial photograph of unknown origin. Possibly originators are US DoD, USDA, USGS. Kept on file at RRMC, Apr 23, 1938.

Property map of land acquisition dated 1952. 


\section{Appendix A: Related Documents}

Figure 1. 2002 letter from the Pennsylvania Historical and Museum Commission (PHMC) to Fort Detrick in regards to the 2001 Baltimore District survey of Site R.
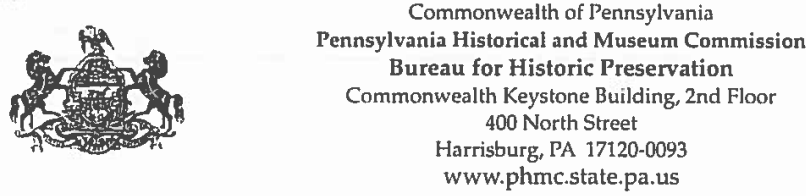

Commonwealth of Penssylvanis

Pennsylvania Historical and Museum Commission

Bureau for Historic Preservation

Commonwealth Keystone Building, 2nd Floor

400 North Street

Harrisburg, PA 17120-0093

www.phmc.state.pa.us

Department of the Army

January 29,2002

Headquarters, U.S. Army Garrison

Attn: Betty Boyland, Cultural Resource Manager

810 Schreider Street

Fort Detrick, MD 21702-5000

Re: ER\# 01-2502-001-B

DOD: Final Phase I Report, Alternate Joint

Communications Center - Site R, Raven Rock

Mountain, Liberty Township, Adams County

Dear Ms. Boyland:

The Bureau for Historic Preservation (the State Historic Preservation Office) has reviewed the above named report in accordance with Section 106 of the National Historic Preservation Act of 1966, as amended in 1980 and 1992, and the regulations (36 CFR Part 800) of the Advisory

Council on Historic Preservation. Our comments are as follows:

Thank you for providing the additional copies of this report as requested. The two historic farmstead sites identified through this investigation have been recorded in the Pennsylvania Archaeological Site Survey files and assigned the following numbers:

J. Ferguson - 36 Ad 339

S. Kline - 36 Ad 440

It is our understanding that these sites will not be affected by any project activities and will be preserved in place.

If you have any questions or comments concerning our review, please contact Mark Shaffer at (717) $783-9900$

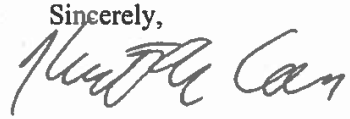

Kurt W. Carr, Chief

cc: Scott Watson, COE/Baltimore

Division of Archaeology \& Protection 
Figure 2. 2009 letter from Gettysburg National Military Park in regards to the stone structure near the East Gate.

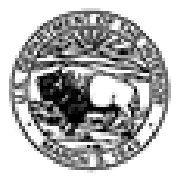

\section{United States Department of the Interior} NATIONAL PARK SERVICE

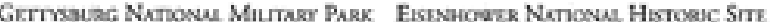
Getrysburg, PA $17325 \quad$ Getryburg PA 17325

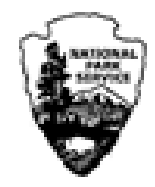

A3815 (H30)

October 28,2009

Memorandum

To:

Ellen A. Britsel

Strategic Commanications Officer

Raven Rock Mountain Complex

Washington Headquarters Services

From: Winona R. Peterson, Gettysburg National Military Park

Subject: Trip Report: Site Visit Conducted October 22, 2009

Gettysburg National Military Park senier historian Kathleen G. Harrison, cultural resource specialist Winona R. Peterson and seasonal employee Gary Thomas were invited to investigate potential cultural features located within the boundaries of the Raven Rock Mountain Complex. On Thursday, October 22, 2009 these individuals were allowed to view two sizeable dry-laid rock structures. Prior to coming on site the historians condacted peeliminary research in an attempt to find documentary evidence to support the supposition that these dry laid stone foundations were constructed for use as signal statioas during the Civil War. It should be noted that this research was very limited and included a very cursory search of the Official Records, and internet searches of Antietam National Battlefield and Monterey Pass Battlefield Association websites.

Both of these features are located in such a way as to provide long views through gaps in the south mountain. One is built on a large rock cuterop and overlooks the small village of Fountaindale. The other is situated for visibility south over Harbaugh Valley Rosd and is built upoe the soil. The sarrounding terrain is very steep and the woods were littered with dry-laid stone walls. In addition, the foundation built upon the rock appeared to have been accessible from two road traces that were still visible ia the landseape. There was vegetation surrounding both features. The understory vegetation had been cleared back prior to our visit. Many of the trees behind the foundations were large, the ones that had grown up in front appeared to be much younger in age. It was noted that these views had been cleared during the mid $-20^{\mathrm{A}}$ century.

Based upon the evidence found in the field it does indeod appear that these rock structures were used as foundations for signal stations of some sort, most likely of the Civil War era. It is likely that the rock esed to construct them came from the stone walls erected by the families who settled the area. It is difficult to imagine any other use for these very unique structures.

TAKE PRIDE'

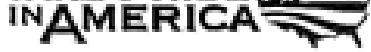


Figure 2. Cont'd.

GNMP Trip Visit Report 10-22-09 Continued

NPS staff recommended that a more thorough investigation of the Official Records and other military records be conducted as well as searches into the local historical society records. Peterson will send electronic copies of the limited research she did to Raven Rock staff. NPS also recommended that an archeological investigation be conducted within the general vicinity of these structures in an attempt to confirm their provenance. Since the installation is located in Adams County Pennsylvania it was recommended that Raven Rock staff contact the Pennsylvania Historical Museum Commission (PHMC) for guidance on how best to proceed. Peterson forwarded contact information to Ms. Ellen Britsch at Raven Rock to facilitate this discussion. She also contacted Mark Shaffer of PHMC to advise that a conversation would be forthcoming.

It was a rare treat to be included in the dialog concerning these interesting structures. 
Figure 3. 2010 letter from PHMC in regards to the stone structure near the East Gate.

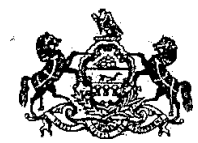

June 1,2010

Commonwealth of Pennsylvania

\section{Pennsylvania Historical and Museum Commission}

Bureau for Historic Preservation

Commonwealth Keystone Building, $2^{\text {nd }}$ Floor

$$
400 \text { North Street }
$$

Harrisburg, PA 17120-0093

www.phmc.state.pa.tus

Department of Defense

Raven Rock Mountain Complex

ATN: John Kober

201 Beasley Drive, Suite 100

Ft. Detrick, MD 21702-5029

Re: Stone Features at Site R, Liberty Township, Adaras County

Dear Mr. Kober:

Thank you for your participation in the site visit for the above named resources. Based on the site visit, BHP and Army Corps of Engineer staff could find no definitive explanation for the function of the stone features on the facility. It appears that the feature in the vicinity of Site Creed could be agriculture-related as there were several stone walls in the vicinity, demarcating cleared areas that could have served grazing animals; it also appears that a Civil War military function is a likely explanation for the rock feature on the eastern portion of Site $R$.

BHP and Corps of Engineers staff feel that further archaeological survey around the features is unlikely to yield any information about the dates, purpose, or builder(s) of these features. To gain a better understanding of the possible Civil War function of the feature(s), BHP and Army Corps staff suggest that Site $R$ staff contact the following organizations for advice and research assistance: Antietam National Battlefield in Maryland, Chickamauga and Chattanooga National Military Park in Tennessee, the National Park Service's American Battlefield Protection Program in Washington D.C., and the U.S. Army Military History Institute in Carlisle.

Since these features are obviously man-made but their function is unknown, and since no work that could impact them is planned, BHP staff feels that it is unnecessary to evaluate their eligibility for the National Register at this time. If work that could impact these features is planned, Site R staff should determine their function and eligibility before proceeding.

If you have questions about the National Register please contact Keith Heinrich at (717) 783-9919 or kheinrich@state.pa.us; if you have questions related to Section 106 or 110, contact Mark Shaffer at (717) 783-9900 or mshaffer@state.pa.us.

Sincerely,

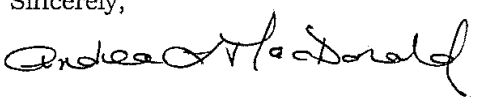

Andrea L. MacDonald, Chief

Division of Preservation Services

ALM $/ \mathrm{kh}$ 


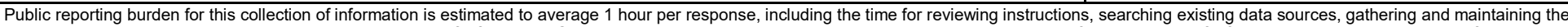

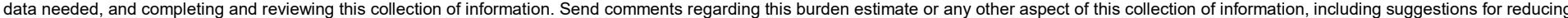

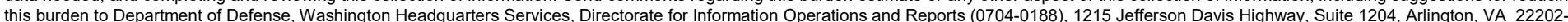

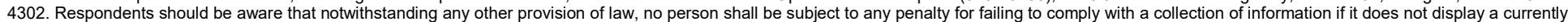
valid OMB control number. PLEASE DO NOT RETURN YOUR FORM TO THE ABOVE ADDRESS

\section{REPORT DATE (DD-MM-YYYY) 08/01/2019 \\ 2. REPORT TYPE Final Technical Report (TR)}

\section{TITLE AND SUBTITLE}

Raven Rock Mountain Complex Site R, PA Archaeological Site Revisit

6. AUTHOR(S)

Carey. L. Baxter, Adam D. Smith, and Ellen R. Hartman

\section{PERFORMING ORGANIZATION NAME(S) AND ADDRESS(ES)}

U.S. Army Engineer Research and Development Center (ERDC)

Construction Engineering Research Laboratory (CERL)

PO Box 9005,

Champaign, IL 61826-9005

\section{SPONSORING / MONITORING AGENCY NAME(S) AND ADDRESS(ES)}

Raven Rock Mountain Complex

Environmental Safety, Health and Industrial Hygiene Department

Fairfield, PA 17320

\section{DISTRIBUTION / AVAILABILITY STATEMENT}

Approved for public release; distribution is unlimited.

\section{SUPPLEMENTARY NOTES}

This study was funded by Raven Rock Mountain Complex, under reimbursable Project 469449, "Work for RRMC."

\section{ABSTRACT}

The U.S. Congress codified the National Historic Preservation Act of 1966 (NHPA) in part by establishing the National Register of Historic Places (NRHP), which requires federal agencies to address their cultural re-sources. NHPA Section 110 requires federal agencies to inventory and evaluate their cultural resources, and Section 106 requires them to determine the effect of federal undertakings on those potentially eligible for the NRHP.

In 2017, ERDC-CERL was tasked with conducting a Phase I Archaeological survey of Raven Rock Mountain Complex (RRMC) Site $\mathrm{R}$ in Pennsylvania, which was built in 1951 and is now a division of the Washington Headquarters Service. In 2001, U.S. Army Corps of Engineers Baltimore District conducted an archaeological Phase I survey of the Site R facility. A 2017 historical resources survey of the facility recommended additional archaeological resources research to supplement the 2001 survey. This report provides supplemental historic context and field documentation of archaeological sites and features described in the 2001 report. In consultation with the Pennsylvania State Historic Preservation Officer, this work fulfills Section 110 processes for the land at Site R.

\section{SUBJECT TERMS}

Archaeological site location, Historic preservation, Cultural property--Protection, Archaeology, Military bases

\section{SECURITY CLASSIFICATION OF:}

\section{a. REPORT}

Unclassified

\section{b. ABSTRACT}

Unclassified

\section{c. THIS PAGE}

Unclassified
17. LIMITATION OF ABSTRACT

SAR
18. NUMBER OF PAGES

48 19a. NAME OF RESPONSIBLE PERSON

19b. TELEPHONE NUMBER (include area code) 